The Production and Distribution of Pottery at Pompeii: A Review of the Evidence; Part 1, Production

Author(s): J. Theodore Peña and Myles McCallum

Source: American Journal of Archaeology, Vol. 113, No. 1 (Jan., 2009), pp. 57-79

Published by: Archaeological Institute of America

Stable URL: http://www.jstor.org/stable/20627542

Accessed: 09-11-2015 15:42 UTC

Your use of the JSTOR archive indicates your acceptance of the Terms \& Conditions of Use, available at http://www.jstor.org/page/ info/about/policies/terms.jsp

JSTOR is a not-for-profit service that helps scholars, researchers, and students discover, use, and build upon a wide range of content in a trusted digital archive. We use information technology and tools to increase productivity and facilitate new forms of scholarship. For more information about JSTOR, please contact support@jstor.org. 


\title{
The Production and Distribution of Pottery at Pompeii: A Review of the Evidence; Part 1, Production
}

\author{
J. THEODORE PEÑA AND MYLES MCCALLUM
}

\begin{abstract}
This study, in two parts, reviews the evidence from Pompeii for the production and distribution of pottery. Part 1, the present article, considers the production of pottery. Evidence is scant for the pre-Roman period but includes a refuse deposit containing Black Gloss Ware wasters, a pottery kiln with associated Black Gloss Ware and commonware wasters, and a mold for the manufacture of Italo-Megarian Ware bowls. There is substantially more material for the Roman period, including two frescoes depicting potters, three graffiti referring to potters, and the excavated remains of two modestly sized pottery production facilities, neither of which has been published in detail. The frescoes suggest that potters at Pompeii used rod-driven, single-wheel potter's wheels. The Via di Nocera facility, which manufactured lamps and commonware, is perhaps the most complete pottery production facility from the Roman world, and it is possible to reconstruct the operations carried out in its various spaces in considerable detail. The Via Superior facility, which manufactured cookwares, was only partially excavated, so it is more difficult to infer its operations. Together, these two facilities may have supplied Roman-period Pompeii with much or all of its locally manufactured cookwares, commonwares, and lamps. Part 2, which will appear in a forthcoming issue of the AJA, examines the material basis for pottery production at Pompeii (i.e., the availability and use of raw materials) and its distribution.*
\end{abstract}

\section{INTRODUCTION}

Pottery represents the most abundant category of portable material culture in the archaeological record of the Roman world, and studies of the pottery industry have played a major role in efforts to elucidate both the

*J. Theodore Peña would like to express his appreciation for the assistance of the Interlibrary Loan Department at the University at Buffalo's Lockwood Library for providing a large portion of the works that he consulted in writing his portions of this article, to Rex Wallace for providing insight into various aspects of CIL 4 10150, and to Massimo Betello for providing several bibliographical references. Myles McCallum would like to thank Gary Devore and Steven Ellis for permission to publish the two mold fragments from the Porta Stabia Project excavations discussed in this article. All translations craft and agricultural sectors of the Roman economy. Given the importance of pottery studies, it is surprising that there is no systematic review of the evidence for the production and distribution of pottery from that richest of Roman archaeological sites, Pompeii. ${ }^{1}$ This two-part article redresses this situation by assembling and interpreting the Pompeian evidence, considering both what it tells us about specific aspects of the production and distribution of pottery at Pompeii and about the pottery industry in the Roman world more generally. ${ }^{2}$ Part 1 , the present article, reviews the evidence for the production of pottery at Pompeii. Part 2, to appear in a forthcoming issue of the $A J A$, examines the material basis for pottery production at Pompeii (i.e., the availability and use of raw materials) and its distribution. As the bulk of the evidence dates to the roughly 160 years of Pompeii's Roman period (ca. 80 B.C.E.-79 C.E.), the discussion focuses on this phase of occupation.

\section{POTTERY PRODUCTION DURING THE PRE-ROMAN PERIOD}

The evidence for the production of pottery at Pompeii during the pre-Roman period is sparse, consisting of debris from a deposit not clearly associated with a pottery production facility, a probable kiln with associated debris, and the sporadic find of a mold. ${ }^{3}$

Excavation was carried out in 1980 though 1981 in an approximately $400 \mathrm{~m}$ long trench traversing the southwest quarter of the town from the House of Bac-

are by Peña.

${ }^{1}$ For a brief overview of pottery production at Pompeii, see Bon-Harper 1999.

${ }^{2}$ This study does not generally take into consideration the evidence for the production and distribution of architectural ceramics, opus doliare (i.e., dolia and mortaria), or terracotta sculpture.

${ }^{3}$ The term "pottery production facility" refers to the place where pottery was manufactured, including the various structures and facilities involved in the production process. 
chus (VII.4.10) to the Sanctuary of Venus (VIII.1.3). ${ }^{4}$ It involved the partial excavation of a series of dump deposits along the southern side of the Via Marina, immediately outside the Basilica (VIII.1.1-2) (fig. 1[1]). ${ }^{5}$ These deposits, which were cut by the foundation trench of the north wall of the Basilica, were dated by Arthur to the late fourth or early third century B.C.E. They contained an unspecified number of Black Gloss Ware sherds and kiln spacers. The sherds showed no signs of use, and, according to Arthur, some were misfired. He concluded that these materials represented production debris from a pottery production facility, probably in the southwestern quarter of Pompeii.

Three different vessel forms were represented among the group of materials: the skyphos, the kylix, and the hemispherical bowl (fig. $2 \mathrm{a}-\mathrm{c}$ ). Several of the vessels belonging to the group had impressed decoration in the interior of their floor in the form of small palmette stamps arranged in a radial pattern. Two of these have a tall ring foot with a distinctive ridge on the exterior face and what should probably be reconstructed as a set of four stamps on the interior of the floor; a third may have had five stamps. Arthur did not provide any information regarding either the fabric of these vessels or the characteristics of their slip. All the kiln spacers present-two rings about $8 \mathrm{~cm}$ diameter and $2 \mathrm{~cm}$ high and a cylinder about $4 \mathrm{~cm}$ diameter and $4 \mathrm{~cm}$ high (see fig. $2 \mathrm{~d}$, e)-were probably for setting the vessel forms just described. ${ }^{6}$ Several Black Gloss Ware kylikes with morphological characteristics and decoration similar to those attested at Pompeii are known from tombs dating to the second half of the fourth century in the Bay of Naples region. ${ }^{7}$

A test trench recently excavated in the small, unnamed house at VII.15.9-10, in the Vicolo Storto Nuovo (formerly Vicolo del Gallo) (see fig. 1[2]), a short distance to the northwest of the Sanctuary of Apollo, uncovered part of an updraft pottery kiln with associated deposits of production debris. ${ }^{8}$ Extant are a wall stump in refractory brick and an adjacent surface composed of lime and small ceramic fragments that

\footnotetext{
${ }^{4}$ The region/insula/doorway addresses conventionally assigned to structures at Pompeii are presented when a structure is first mentioned in the text.

${ }^{5}$ Arthur 1986, 31-3.

${ }^{6}$ For schematic drawings illustrating how kiln spacers of these two kinds were likely employed for the setting of vessels, see Stanco 1988, 26, pl. 5C.

${ }^{7}$ For examples from the necropolis at Ponticelli, on the outskirts of Naples immediately to the northwest of Vesuvius, see Giampaola 1985, 306, nos. 88.5, 89.4; 308, fig. 88.5.

${ }^{8}$ Proietti de Santis 2005 . For the construction and functioning of updraft pottery kilns, see Cuomo di Caprio 1976;
}

may represent part of a kiln flue..$^{9}$ These were covered by a thick, reddish deposit, apparently production debris, which included irregularly formed lumps of clay, misfired and waster sherds of Black Gloss Ware and commonware, and tile and amphora sherds. This, in turn, was covered by a thick deposit containing similar production debris that appears to be a leveling fill for the construction of the house in the second half of the second century B.C.E. These remains suggest the presence here of a pottery production facility for both Black Gloss Ware and commonware sometime prior to the second half of the second century B.C.E. No information is available regarding the specific forms produced or their fabrics, and it is unclear whether the Black Gloss Ware wasters recovered in the deposit on the south side of the Via Marina might have originated at this establishment.

Finally, excavations carried out in 2005 by the Pompeii Archaeological Project: Porta Stabia Project at a small industrial facility located immediately inside the Porta di Stabia at VIII.7.1 (see fig. 1[3]) uncovered two fragments of a ceramic jolly (i.e., a mold mounted on a potter's wheel inside of which a vessel would be thrown) that served for the production of ItaloMegarian Ware bowls. ${ }^{10}$ This was found in a flooring fill deposited at some point between the early first century C.E. and 79 C.E. Both fragments had a thin coating of mortar, suggesting that at some point they had been reused as fill in floor or wall construction. ItaloMegarian Ware was produced from the middle of the second through the first half of the first century B.C.E., and the stylistic attributes of the two fragments suggest that they date to no later than the early decades of the first century B.C.E. ${ }^{11}$ The fabric contains clinopyroxene, suggesting an origin at or near Pompeii. ${ }^{12}$ The mold was presumably employed for the manufacture of pottery at a pottery production facility at Pompeii, possibly in the vicinity of the Porta di Stabia. This is the only mold for Italo-Megarian Ware recovered to date in Campania and the only known evidence for the production of this class of tableware in southern Italy. ${ }^{13}$

\footnotetext{
Swann 1984, 29-41.

${ }^{9}$ The small chamber through which fuel was introduced into a kiln; also known as the fire tunnel or praefurnium.

${ }^{10}$ McCallum and Manfredi 2007.

11 The decoration on the mold fragments is most closely related to that appearing on Italo-Megarian bowls produced in the workshops of Lapius, in Etruria, and Quintius, at Tivoli (see Puppo 1995, 35-6, 53-4).

${ }^{12}$ This will be discussed in part 2 of this article, to appear in a forthcoming issue of the $A J A$.

${ }^{13}$ To the authors' knowledge, novessels manufactured from
} this mold have been recovered at Pompeii or elsewhere. 


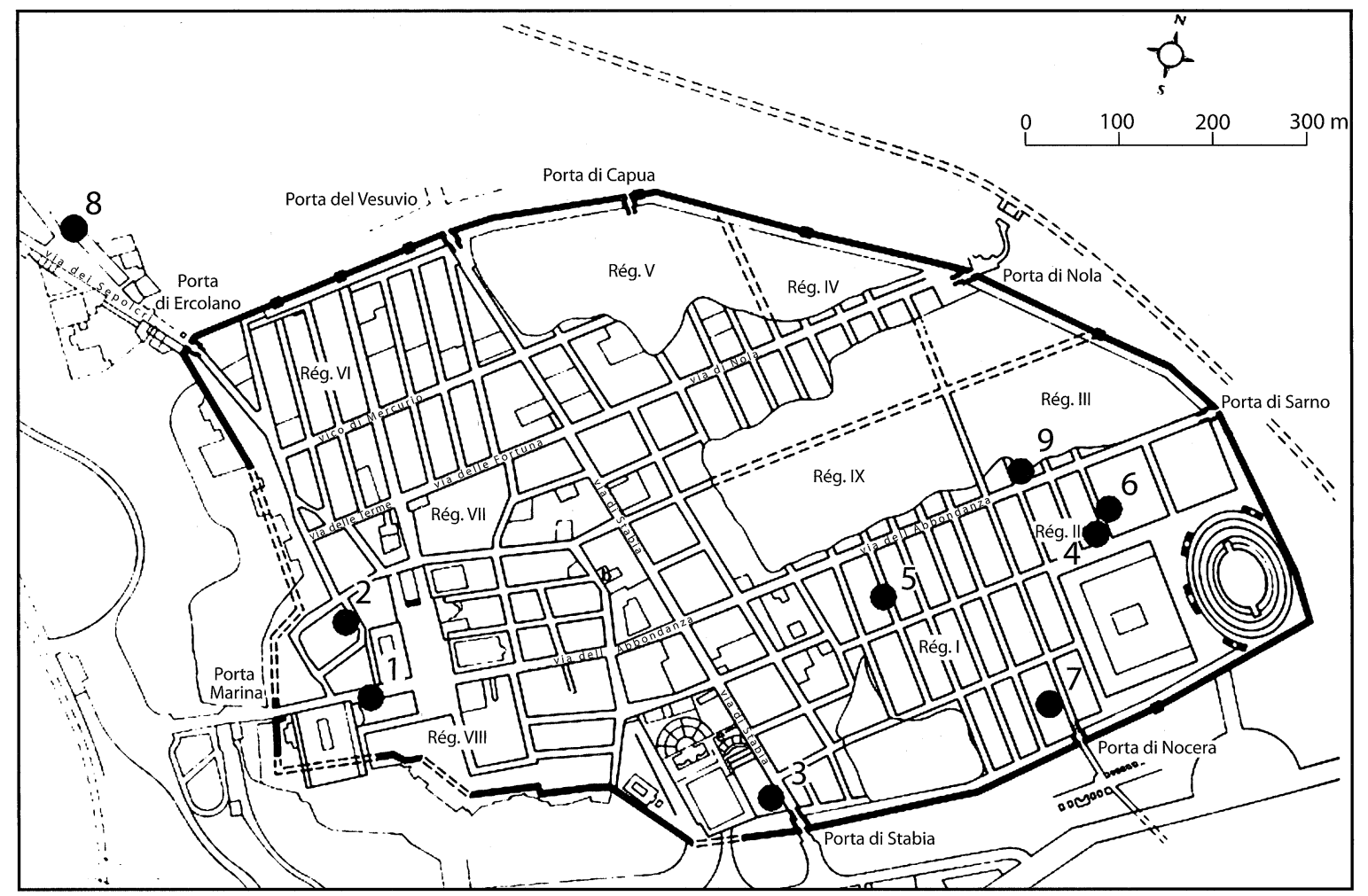

Fig. 1. Map of Pompeii, showing structures and other features discussed in the text: 1, findspot of Black Gloss Ware wasters and kiln spacers; 2, pottery kiln beneath house at VII.15.9-10; 3, findspot of Italo-Megarian Ware bowl mold; 4, Officina Vasaria di Nicanor; 5, Hospitium dei Pulcinella; 6, Praedia Iuliae Felicis; 7, Via di Nocera pottery production facility; 8 , Via Superior pottery production facility; 9, Taberna del Vasaio Zosimo (courtesy Soprintendenza Archeologica di Pompei).

\section{POTTERY PRODUCTION DURING THE ROMAN PERIOD}

\section{Frescoes Depicting Potters}

Two frescoes of Roman date from Pompeii depict potters. One was located on the exterior of the south enclosure wall of the Officina Vasaria di Nicanor (II.3.7/9), to the right/east of its principal entrance (II.3.9) (see fig. 1[4]). ${ }^{14}$ This facility may have been a venue for either the manufacture or sale of pottery (see below, under "Other Facilities Sometimes Identified as Pottery Production Facilities").

The fresco (ht. $0.71 \mathrm{~m}$, wdth. $0.55 \mathrm{~m}$ ) is executed in a realistic manner (fig. 3). Fröhlich assigns this to the early Fourth Style, ${ }^{15}$ suggesting that the work probably dates to ca. 50-60 C.E. On the left stands the god

${ }^{14}$ For this fresco, see Maiuri 1939, 198-200; Pugliese Carratelliand Baldassare 1990-2003,3:181,182, figs. 1,2; Fröhlich 1991, 313, cat. no. F19, fig. 16.1. Following excavation, it was detached from the wall on which it was executed and moved

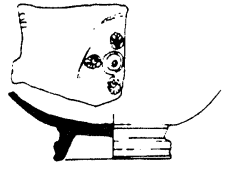

a

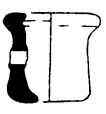

d

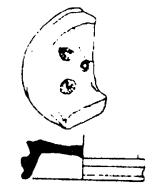

b

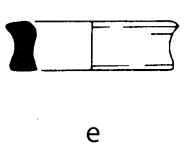

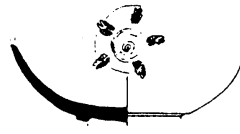

C

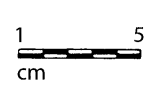

Fig. 2. Black Gloss Ware vessels and kiln spacers from the test trench along the south side of Via Marina: $a$, skyphos; $b$, kylix; $c$, hemispherical bowl; $d$, $e$, kiln spacers (after Arthur 1986, fig. 3; (c) Society of Antiquaries of London).

to the Pompeii Antiquarium, where it was assigned the inventory number 21631.

${ }^{15}$ Fröhlich 1991, 313. 


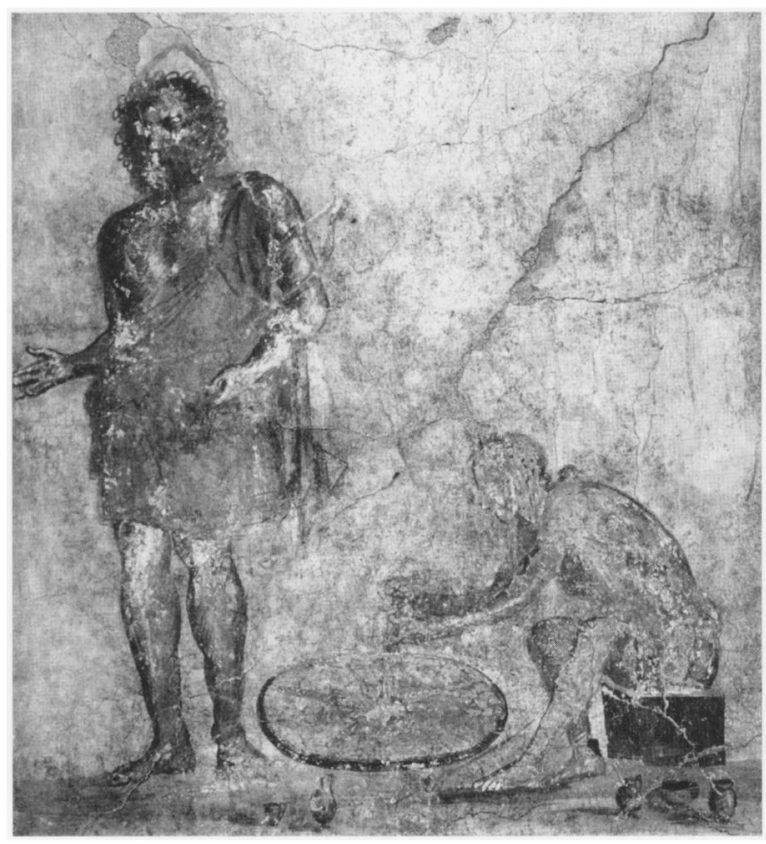

Fig. 3. Fresco depicting Vulcan and potter from Officina Vasaria di Nicanor (๔ Soprintendenza Archeologica di Pompei).

Vulcan, and on the right a potter works at a wheel. The potter sits on a low, block-shaped stool with his ankles crossed; he bends over the wheel, forming a small jar or beaker with both hands. The potter's wheel is a low-set disc, with a diameter roughly equal to the distance from the sole of Vulcan's foot to his knee (notionally ca. $50-65 \mathrm{~cm}$ ), while its thickness is equal to about $1 / 15$ th of its diameter (notionally ca. $3-5 \mathrm{~cm}$ ). A rod rests on the ground at the potter's feet. ${ }^{16} \mathrm{On}$ the ground next to his stool are three small vessels: a juglet with a vertical handle, a hemispherical bowl, and a small jar or beaker similar to the vessel on the wheel. Four small vessels, including a beaker and a jug, rest on the ground to the left of the wheel, near Vulcan's left foot. Vulcan presumably appears in this fresco in his role as the god of the furnace and, by extension, the patron of potters. A fresco depicting Minerva and Mercury, the patrons of craftsmen and

\footnotetext{
${ }^{16}$ Maiuri (1939, 198), followed by Fröhlich (1991, 313), believed that a dark area near the potter's left foot and the rod represented a treadle device of some kind that served to propel the wheel. Zimmer $(1982,199)$ termed the rod a Modellierstab (forming rod), while identifying the dark area as a treadle.

${ }^{17}$ For this facility, see Maiuri 1953-1954; Van der Poel et al. 1986, 14, 15; Castiglione Morelli del Franco and Vitale 1989, 197-99; Pugliese Carratelli and Baldassare 1990-2003, 1:826-
}

commerce, respectively, was located on the same wall as this fresco, to the left of the doorway.

The second fresco depicting potters was located on the exterior wall of the Hospitium dei Pulcinella (I.8.10), ${ }^{17}$ immediately to the right/north of a blocked doorway that once connected the room in the southeast corner of the structure-Room 5 by Maiuri's numbering - with the unnamed street marking the east side of the insula (see fig. 1[5]). ${ }^{18}$ Its presence suggests that Room 5 at one point served as a pottery shop. The surface of the fresco was scored with pick blows to facilitate the adherence of a (partially preserved) layer of plaster. The fact that the fresco was executed prior to the blocking of the door and then covered over suggests a date substantially earlier than 79 C.E. Fröhlich suggested a date between 100 B.C.E. and 50 B.C.E. ${ }^{19}$

The fresco (lgth. $1.38 \mathrm{~m}$, ht. $0.59 \mathrm{~m}$ ) is executed in an outline style (fig. 4). It is divided into two sections set side-by-side. The left section (lgth. $0.72 \mathrm{~m}$, ht. 0.57 $\mathrm{m}$ ), which is missing much of its upper left corner and left edge, depicts activities inside a pottery production facility. The right section, which depicts two figures in an upper register and a Pygmy next to a loom or workbench in a lower register, belongs to a different scene.

The central and right portions of the left section present four depictions of a potter forming a vessel on a wheel. These are arranged in two registers, with two potters in each. In all four depictions, the potter sits on a tall, three-legged stool in front and to the right of the wheel. The potter at the upper left is largely missing, with just his legs and those of the stool on which he is seated preserved. In the other three, the potter has both hands placed on or above a vessel positioned at the center of his wheel. In each case, the wheel, at roughly the height of the potter's waist, is a thick disc on a tall, conical support; a rod is propped diagonally against the wheel's edge. The vessel on the wheel of the potter at the upper right appears to have a rounded body, possibly a short, constricted neck, with a broad, everted rim. The vessel on the wheel of the potter at the lower left has tall, nearly vertical walls, while that on the wheel of the potter at the lower right has a rounded body, short, slightly constricted neck,

33; Eschebach 1993, 44-5; Wallace-Hadrill 1994, 190, 191, fig. A2.

${ }^{18}$ For this fresco, see Maiuri 1953-1954, 90-2; Fröhlich 1991, 307-8, cat. no. F5. Following excavation, it was detached from the wall on which it was executed and moved to the Pompeii storerooms, where it was assigned the inventory number 45622.

${ }^{19}$ Fröhlich 1991, 308. 
and a broad mouth. A woman or girl stands between the two potters in the lower register, facing the potter at the right and holding out two vessels similar in appearance to the vessel on the wheel of the potter at the lower left. To the left of the four potters is part of an element that Maiuri identified as the lower part of a xoanon of Minerva; to the left of that is an altar with a flame burning on its upper surface.

It is unclear whether this scene should be read as four different potters at work simultaneously in the same facility or as a single potter at four different stages in the forming of a vessel..$^{20}$ The distinction is an important one: in the first reading, this would be evidence for the existence at Pompeii or in the broader Bay of Naples region of large pottery workshops engaged in intensive production. ${ }^{21}$ The vessels shown on the wheels in the lower register, one a tall cylinder that perhaps constitutes an intermediate stage in the throwing of a closed form and the other perhaps the same vessel after the potter has formed its neck and shoulders by collaring, are not incompatible with the second reading. The woman shown in the lower register may be carrying away vessels finished by the potter at the lower right or passing partially formed vessels produced by the potter at the lower left to the potter on the lower right for completion. ${ }^{22}$

These two frescoes are important to our understanding of the nature of potter's wheels in the Roman world, a topic about which surprisingly little is known. ${ }^{23}$ Together, they strongly suggest that potters active at Pompeii during the Roman period used wheels of the rod-driven, single-wheel type rather than the kick-wheel driven, double-wheel type, the design favored by potters working in Europe and the Mediterranean during the modern period. ${ }^{24}$ Wheels of the single-wheel type are widely used today by traditional potters in many parts of the Indian subcontinent, ${ }^{2.5}$ and it seems likely that Roman-period potters at Pompeii used wheels similar in construction and operation.

The single-wheel wheels used by Indian and Pakistani potters have a disc about $0.5-1.3 \mathrm{~m}$ in diameter crafted from a variety of materials, including wood,

\footnotetext{
${ }^{20}$ Maiuri's (1953-1954, 91) belief that the four men represent travelers presenting offerings to Minerva on offering tables should be rejected.

${ }^{21}$ The term "workshop" refers to the unit of production, consisting of one or more laborers organized in any of several possible arrangements.

${ }^{22}$ On this question, see Rieth 1965; Prachner 1980, 191; Fülle 1997, 135.

${ }^{23}$ For potter's wheels in the Roman world, see Czysz 1982, 322-30; Peacock 1982, 55-8; Mackensen 1993, 64-7.

${ }^{24}$ To the authors' knowledge, there is no definitive evidence for the use of double-wheel type potter's wheels in the
}

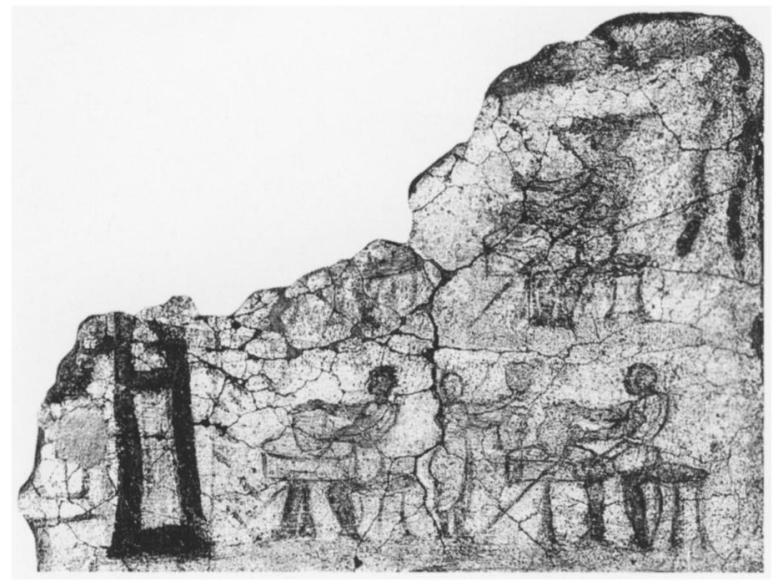

Fig. 4. Fresco depicting four potters and a female assistant from Hospitium dei Pulcinella (๑ Soprintendenza Archeologica di Pompei).

stone, cement, terracotta, clay, or clay packed around a spoked wooden frame. The disc must be heavy enough to function as a flywheel, and in many cases it is either thickened toward the rim or is provided with a flange so as to concentrate more weight in the rim area. The disc may be mounted in two different manners. Sometimes it is provided with a socket at the center of its underside and is mounted on a low pivot set into a flat base (fig. 5). The socket generally consists of a cobble-sized hard stone, such as quartzite, that has a hole bored in one side. The pivot is generally made of a hard wood, while the base may consist of a large, flat stone, a cement disc, or a wooden disc. In many cases, the base element is set into the ground or pavement to keep the wheel firmly in place. Alternately, the disc is provided with a pivot bar at the center of the underside and is mounted on a socket stone set into the center of a shallow pit. Potters generally set the wheel in motion with their hands, insert a rod of some kind into a hole cut into the upper surface of the disc near its edge, and use this to spin the wheel fast enough to throw a vessel (fig. $6)$. They then disengage the rod and squat beside the

Roman world. Representational evidence indicates that potter's wheels with a small, lower kick wheel connected to an upper wheel head by several struts were in use in Europe by the middle of the 13th century, while wheels with a large, lower kick wheel functioning as a flywheel connected to an upper wheel head by a single iron axle were in use there by the first half of the 16th century (McCarthy and Brooks 1988, 29-30; Cuomo di Caprio 1995, 148).

${ }^{25}$ For single-wheel type wheels in the Indian subcontinent, see Rye and Evans 1976, 87-8; Miller 1985, 207, 208, fig. 54; 215; Kramer 1997, 58, 62. 


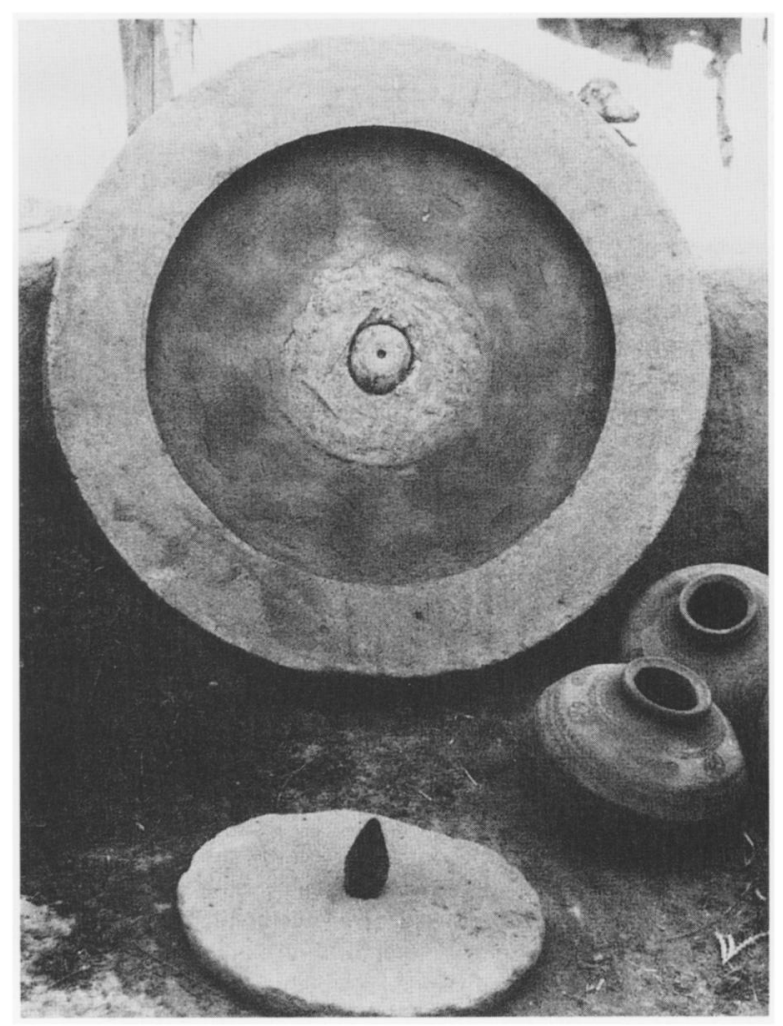

Fig. 5. Single-wheel type potter's wheel of socketed variety dismounted from its pivot. Dangwara, India (Miller 1985, fig. 54; @ Cambridge University Press).

wheel, forming vessels until the wheel slows, at which point they reinsert the rod and bring the wheel back up to speed to continue throwing.

It would be unwise to assume that either fresco provides an accurate representation of the technical details of the potter's wheels in use at Pompeii during the Roman period. However, in neither case is there any indication that the wheels were mounted inside a pit; this suggests that these were of the socketed rather than the pivoted variety. The three wheels depicted in the Hospitium dei Pulcinella fresco have much thicker discs and much taller supports than any singlewheel type wheels documented in the ethnographic record. Given the rough execution of these frescoes, however, it seems possible that the artist exaggerated the wheels to make them interpretable. The fact that the artist showed such thick discs may mean that he intended to depict flanged discs, while the conical shape of the support again suggests that he intended

\footnotetext{
${ }^{26}$ Kramer 1997, 62.

${ }^{27}$ Kramer 1997, 49, fig. 19; 63, fig. 27; 64, fig. 28.

${ }^{28}$ Maiuri 1927, 12; Spinazzola 1953, 687-89, 1011 n. 453. This vessel was recovered from a 79 C.E. context during exca-
}

to represent wheels of the socketed rather than the pivoted variety.

Single-wheel type wheels have one obvious disadvantage but two clear advantages over the double-wheel type. The disadvantage, of course, is that the potter cannot propel the wheel while simultaneously using his hands to form a vessel and must therefore either complete the vessel on which he is working before the wheel slows or interrupt his work in order to bring the wheel back up to throwing speed. One advantage is that the single-wheel type is relatively portable. While double-wheel type wheels are large, heavy, and complex devices that are, as a rule, mounted in a specific place and left there until replaced, single-wheel type wheels-particularly those of the socketed varietycan be readily removed from their mounting. Singlewheel type wheels can thus be stored out of the way when there are no throwing operations in progress, creating space for other activities, and can be set up for use in different locations as conditions may require. Potters in India, for example, sometimes shift the location of their wheels with the seasons, moving them from a sunny area to a shady one, or from a covered space to a rooftop. ${ }^{26}$ The second advantage is that, unlike double-wheel type wheels, which generally have a built-in bench on which the potter sits, single-wheel type wheels allow the potter to move while he works. Since one of the most important constraints in throwing is the need to clear away freshly thrown vessels to make room for new ones, the ability to shift one's position allows a potter to set aside freshly thrown vessels over a larger area than would otherwise be the case, continuing to work unassisted and without interruption for a relatively long period of time. It is evident from photographs of Indian potters throwing at a single-wheel type wheel that they often orbit the wheel as they work, creating a halo of newly formed vessels around the wheel that measures as much as 4-5 $\mathrm{m}$ across (fig. 7). ${ }^{27}$

\section{Graffiti Referring to Potters}

There is one Roman-period graffito from Pompeii that without question refers to a potter and another two that may refer to potters. The text that certainly mentions a potter is a praecocturam graffito scratched into a large (ht. $0.86 \mathrm{~m}$ ) jug of uncertain class that is covered with an intricate network of applied pellets, applied strips of clay, and incised circles (fig. 8) ${ }^{28}$ This vessel was presumably manufactured either at Pompeii

vations carried out in 1923 in the Casa di M. Fabius Amandio (also known as the Casa del Vasaio Corinthus) (I.7.2-3). The fate of this vessel is not known to the authors. The closest parallels from Pompeii for its elaborate decorative scheme occur 
or somewhere else in the Bay of Naples region. The text, located under one of the handles, reads:

\author{
... ] P. Corneli \\ Corint(h)i servos \\ fecit \\ [personal name] \\ the slave of Publius Cornelius Corinthus \\ made (this) ${ }^{29}$
}

The Publius Cornelius Corinthus who owned the slave potter is otherwise unattested at Pompeii, where Cornelii abound.$^{30}$ It cannot be excluded that he was the same man as the slave named Corinthus who, working in the figlina (tile workshop) of C. Cluentius Ampliatus, signed a flanged tile found in the Casa di Messius Ampliatus (II.2.4) and also had his name stamped on two dolia recovered at Pompeii. ${ }^{31}$ Nor can it be excluded that he was the same Corinthus-presumably also a slave-who had his name stamped on several examples of Italian sigillata manufactured at Puteoli ca. 1-30 C.E. ${ }^{32}$ If either identification is correct, it would follow that this Corinthus continued to work in ceramic production following his emancipation from a master named Publius Cornelius, eventually coming to direct his own workshop and own at least one slave potter.

Two other graffiti, both from the Praedia Iuliae Felicis (see fig. 1[6]), perhaps refer to potters. The first is a one-line text about $2 \mathrm{~m}$ in length that was scratched into the wall of a secondary access corridor on the west side of this establishment (II.4.10). It reads:

[cum] de[d]uxisti octies tibi superat ut (h)abeas sedecies coponium fecisti cretaria fecisti salsamentaria fecisti pistorium fecisti agricola fuisti aere minutaria fecisti propola fuisti laguncularia nunc facis si cunnu(m) lin $\mathrm{x}<\mathrm{s}>\mathrm{e}<\mathrm{e}>\mathrm{ris}$, consummaris omnia.

Since you've held eight jobs all that's left for you now is to have 16. You worked as a cook, you worked as a clay man, you worked as a pickler, you worked as a

on thin-walled ware and the so-called vaso magico pots, and it may perhaps be a product of a workshop that manufactured vessels belonging to one of these classes.

${ }^{29}$ See fig. 8. Although Maiuri $(1927,12)$ did not indicate that the text was missing any letters at its beginning, a personal name must be provided in this position for it to make sense. Maiuri did, however, note that the graffito was "guasta da posteriore compressione," raising the possibility that the first word was erased-inadvertently or otherwise-at some point during the handling of the vessel prior to its being dried to a leather-hard state. Alternatively, the name may have been written separately from the rest of the text on some other part of the vessel and been overlooked by Maiuri.

${ }^{30}$ For a "Cornelius L. f. Cori[..." in an inscription probably originating at or near Capua, see CIL 103775.

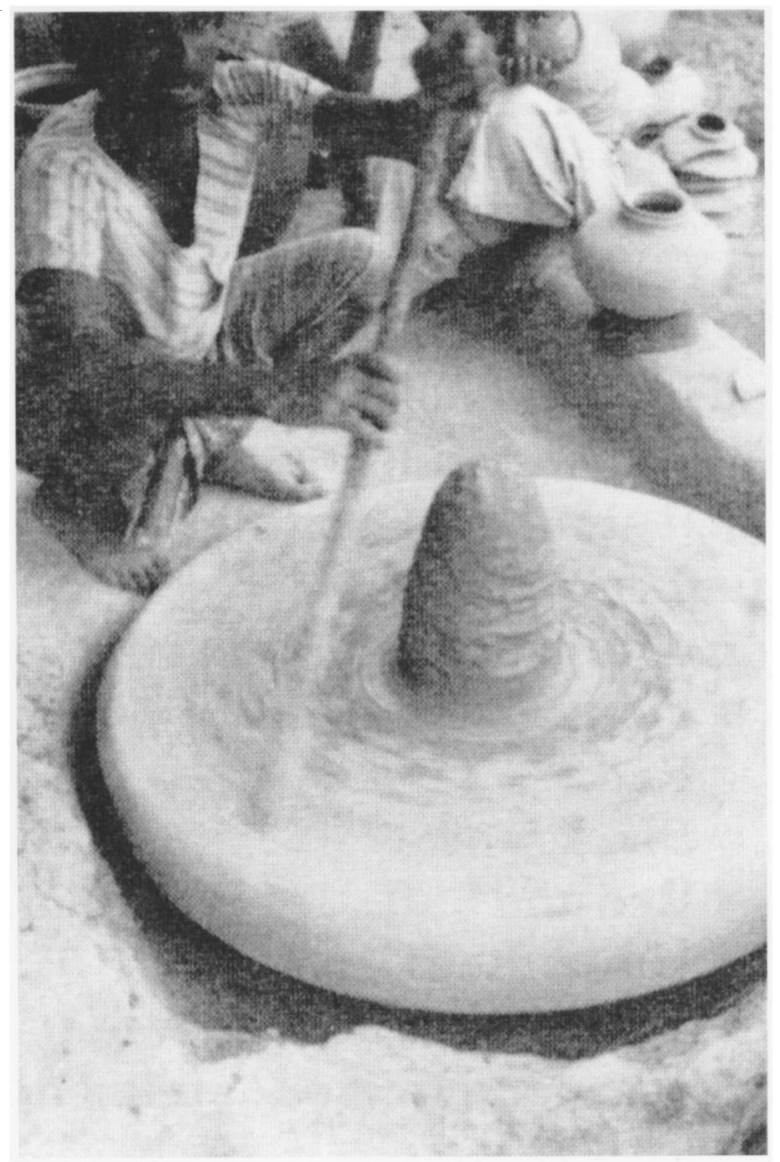

Fig. 6. Potter using a rod to bring a single-wheel type potter's wheel up to throwing speed. Dangwara, India (Miller 1985, fig. 61b; (C) Cambridge University Press).

baker, you were a farmer, you worked as a maker of bronze trinkets, you were a retailer, now you work as a jug man. If you perform cunnilingus you'll have done everything. ${ }^{33}$

The second and the last of the eight occupations referred to in the text-represented by the adjectives

${ }^{31}$ CIL 108047 7. For the flanged tile, see Spinazzola 1953, 687-89. Spinazzola $(1953,687)$ incorrectly believed that Corinthus was the name of the slave potter who manufactured the vessel bearing the graffito here under discussion, identifying him with the Corinthus whose name appears on the flanged tile and two dolia. That opus doliare was manufactured by specialist craftsmen distinct from potters in Roman Campania is suggested by a funerary altar from Calatia (CIL 10403 ), generally datable to ca. 50-200 C.E., on which the dedicant identifies himself as a doliarius (maker of dolia). For this monument, see Zimmer 1982, 201, no. 146.

${ }^{32}$ Oxé et al. 2000, 188, no. 608.

${ }^{33}$ CIL 4 10150. In CIL, the text is divided into four sections termed verses. For this text, see also Della Corte 1958, 128-30, no. 268; Baldi 1964, 794-97. 


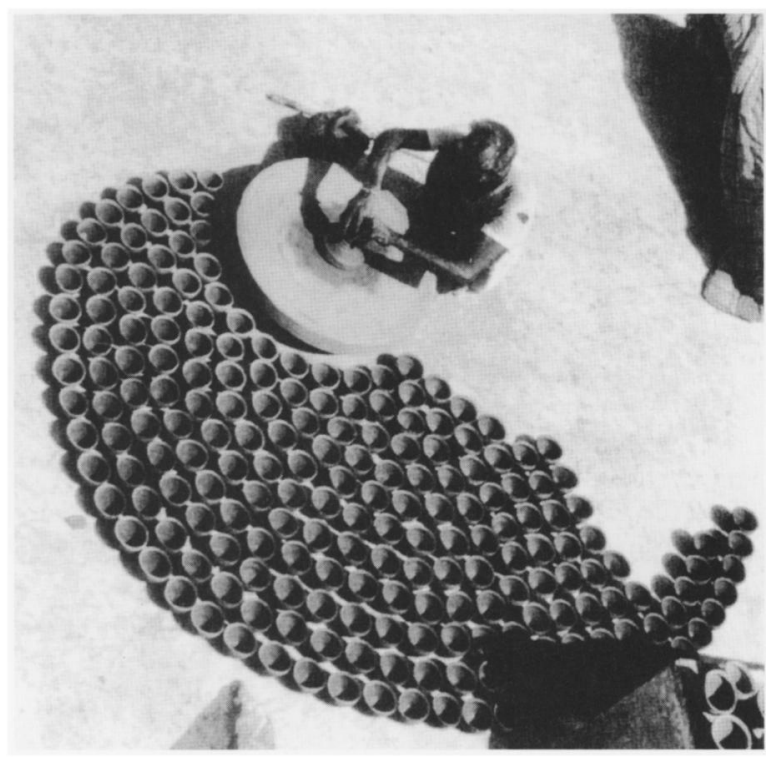

Fig. 7. Potter throwing at a single-wheel type potter's wheel set up on a flat roof. Jodhpur, India. Note the rod for propelling the wheel on the ground next to the potter and the pattern of pots indicative of orbiting (Kramer 1997, fig. 28).

cretaria and laguncularia-are here of interest. ${ }^{34}$ The first indicates a person whose work involved clay in some capacity, although it is uncertain whether this should be understood as a digger or provider of clay, a potter, or brick maker, or even a seller of products in terracotta. ${ }^{35}$ The second term is similarly ambiguous. Laguncula is the diminutive form of lagona/lagoena, a word employed to refer varyingly either to a jug or to an amphora. ${ }^{36}$ While laguncularia may thus refer to a maker of jugs, as Della Corte thought, it might also refer to a maker or seller of amphoras, or perhaps even to someone who earned a living by carrying water in jugs. ${ }^{37}$

\footnotetext{
${ }^{34}$ The six neuter adjectives employed to refer to occupations presumably modify some word such as negotium/negotia. The reason four of these are plural while two are singular is unclear. The other two occupations may have been indicated by means of predicate nouns, since, as nouns of the first declension, these words would have rhymed with the four neuter plural adjectives.

${ }^{35}$ For reference to a taberna cretaria, see Varro Ling. 8.55.

${ }^{36}$ For the use of the words lagona and laguncula in the Latin literary sources, see Hilgers 1969, 204, 205. Persius' Saturae (3.92-3), written ca. 55-62 C.E., refers to the storage of surrentinum (i.e., wine from Surrentum) in a lagoena, perhaps meaning to indicate either an example of the Dressel 2-4 amphora or a table amphora.

${ }^{37}$ An epitaph from Rome probably dating to ca. $50-150$ C.E. (CIL 6 37807) indicates the occupation of the deceased
}

The second of the two graffiti from the Praedia Iuliae Felicis is a one-line text from the same wall as the first:

\section{Scutularius cum Africana hac \\ the scutularius [did it] with the African woman ${ }^{38}$}

As the word scutula was used to denote a serving dish, the term scutularius presumably referred to a maker of serving dishes. ${ }^{39}$ Whether these would have been in pottery or some other material, such as silver, however, is unclear. The association of this occupation with the two mentioned in the other graffito from this space, cretaria and laguncularia, does, however, suggest that all three probably had something to do with the manufacture and/or distribution of pottery. This inference is strengthened by the fact that the corridor in which these two inscriptions appear is located almost directly across a narrow secondary street from the side entrance to the Officina Vasaria di Nicanor, a possible facility for the production and/or sale of pottery.

\section{Remains of Pottery Production Facilities}

Excavation at Pompeii has uncovered the remains of two Roman-period pottery production facilities, both of which were active immediately prior to the town's destruction. Three other structures of the Roman period are also sometimes identified as pottery production facilities, although there is no evidence that any of these functioned as such.

The Via di Nocera Pottery Production Facility. The Via di Nocera pottery production facility (I.20.2-3) - arguably the best-preserved pottery production facility from the Roman world-fronts on the west side of the Via di Nocera, halfway along its insula, about $45 \mathrm{~m}$ to the north of the Porta di Nocera (see fig. 1[7]). ${ }^{40}$ It was excavated in its entirety down to the 79 C.E. ground surface in 1959 and subjected to a program of cleaning

as negotians Porto Vinario lagonaris, presumably meaning an amphora trader at the Portus Vinarius, a wine-trading district in the city. A second epitaph from Rome (CIL 6 9488), in this case of uncertain date, gives the occupation of the deceased, a female of probable low socioeconomic status, as ad Porta $(\mathrm{m})$ Trigemina $(m)$ lagunara (lagunara at the Porta Trigemina). In this case, it is unclear whether the deceased worked as a buyer or seller of amphoras or as a water carrier. For the interpretation of these texts, see Peña 2007, 115-16.

${ }^{38}$ CIL 4 10155. For this text, see Della Corte 1958, 130, no. 273.

${ }^{39}$ For the use of the word scutula in the Latin literary sources, see Hilgers 1969, 273-74.

${ }^{40}$ For purposes of discussion, it is assumed that the insula in which this facility is located is oriented north-south. 


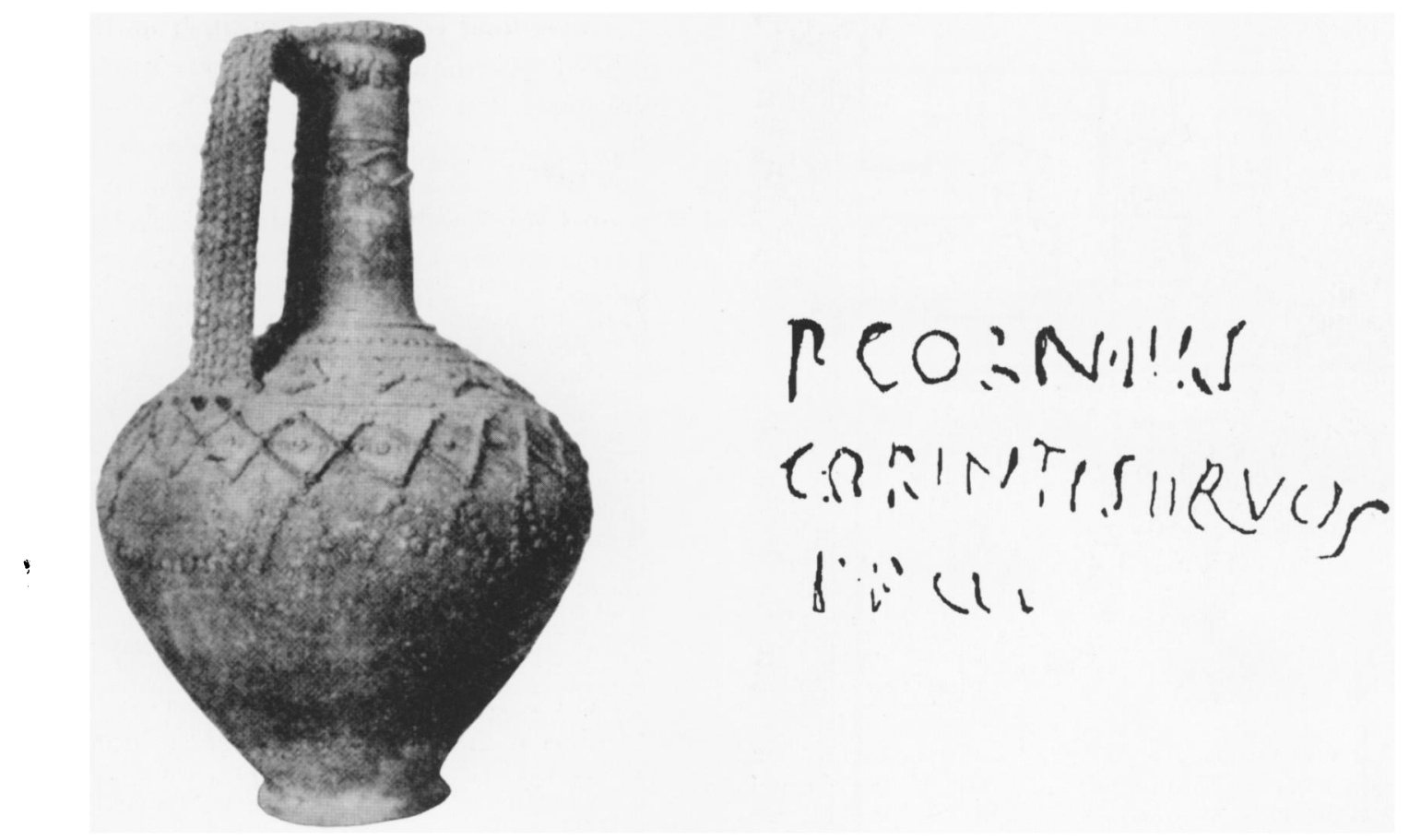

Fig. 8. Vessel of unidentified class (ht. $86 \mathrm{~cm}$ ) with inscribed signature of potter and graffito from Casa di M. Fabius Amandio (Maiuri 1927, fig. 4).

and test excavation in 1973. Although this facility has never been the subject of detailed publication, Cerulli Irelli published a short description of it in $1977 .{ }^{41}$

The building housing the facility occupies the eastern two-fifths of the southernmost lot in the northern half of the insula (fig. 9). It was probably constructed at the time the insula was first developed, apparently during the terminal third century or first quarter of the second century B.C.E. ${ }^{42}$ Whether this structure housed a pottery production facility from the outset is unclear, and it seems possible that the facility was inserted into a row house of Nappo's Type 4, with the western/rear part of the property taken over at that time by the unnamed Type 4 row house that occupies the lot immediately to the north (I.20.4). ${ }^{43}$ Directly to the south is a vineyard known as the Caupona del Gladiatore (I.20.1) with wine pressing, fermentation, and dining facilities, which occupies the entire south-

\footnotetext{
${ }^{41}$ Cerulli Irelli 1977, esp. 53-6, 69-72, figs. 1-12, pls. 26, 27. For this facility, see also Pugliese Carratelli and Baldassare 1990-2003, 2:1060-61, 1066-70; Eschebach 1993, 80-1.

${ }^{42}$ Nappo 1997, 120. Cerulli Irelli's $(1977,54)$ assertion that the facility was inserted into the front left part of a large atrium house is mistaken.
}

ern half of the insula. ${ }^{44}$ The facilities were connected by two ground-floor doorways and a stairway that led from the Caupona del Gladiatore to the mezzanine or roof of the pottery production facility and may well have been operated as a single commercial establishment. This conjecture receives support from the fact that the only doorway connecting the Caupona del Gladiatore with a space other than the Via di Nocera pottery production facility is a narrow (wdth. $1.25 \mathrm{~m}$ ) and-as now reconstructed-low (ht. $1.6 \mathrm{~m}$ ) aperture that opens onto the Via di Nocera immediately to the south of the Via di Nocera pottery production facility (I.20.1).

The facility, which contains five rooms, here termed Rooms 1-5, measures about $9.7 \mathrm{~m}$ north-south by about $11.5 \mathrm{~m}$ east-west, for a ground-floor area of about 112 $\mathrm{m}^{2}$ (fig. 10). Rooms $1-3$ and 5 have a concrete pavement and were presumably roofed, while Room 4, with

\footnotetext{
${ }^{43}$ For this house, see Pugliese Carratelli and Baldassare 1990-2003, 2:1071-78; Eschebach 1993, 81; Nappo 1997, 113-15.

${ }^{44}$ For this establishment, see Jashemski 1979, 227-28; Van der Poel et al. 1986, 36-7; Pugliese Carratelli and Baldassare 1990-2003, 2:1060-65; Eschebach 1993, 80-1.
} 


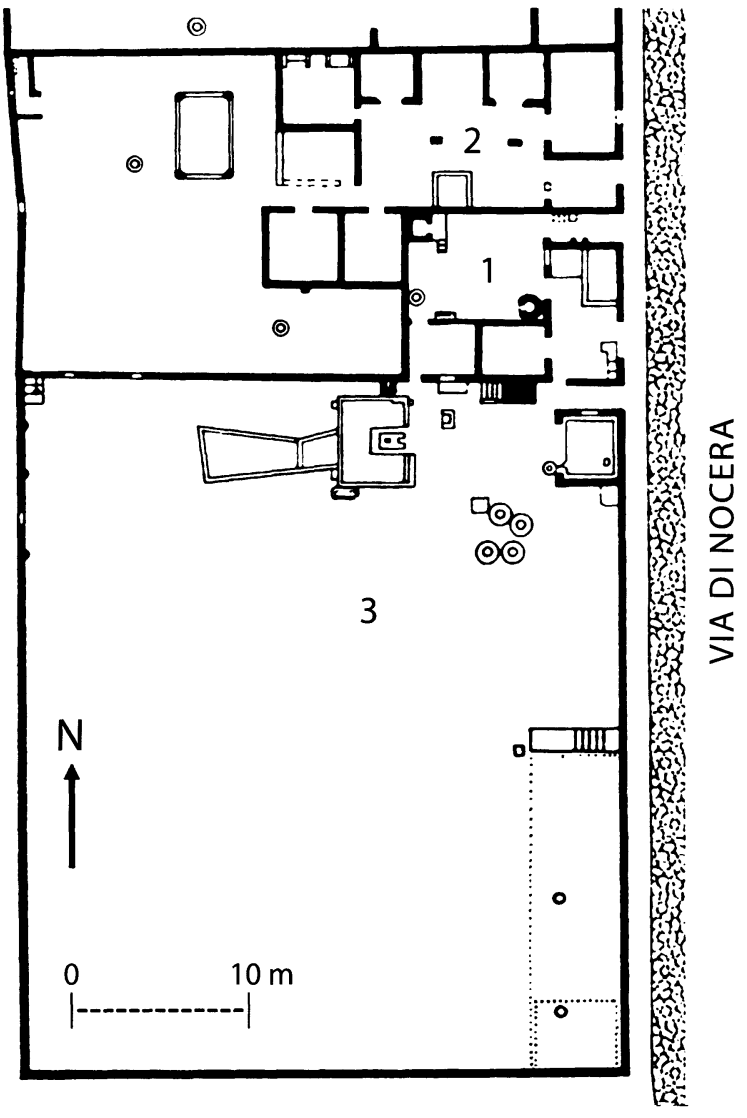

Fig. 9. Plan of the central and southern portions of Regio 1, Insula 20: 1, Via di Nocera pottery production facility; 2, house at I.20.4; 3, Caupona del Gladiatore (after Van der Poel et al. 1986, 37).

its beaten earth floor, was presumably an open court. The walls of all five rooms are surfaced with unpainted plaster. The facility also had either a mezzanine (above Room 1 and perhaps also above Rooms 2, 5, and/or 3) and/or a flat roof where some production activities could also occur.

Room 1 (7.2 m north-south x 3.4 m east-west) occupies the entire front/eastern part of the structure, save for its extreme northern end. There is a doorway (wdth. $2.0 \mathrm{~m}$ ) (I.20.2) in the southern part of its east wall that opens onto the Via di Nocera. The threshold currently in place here consists of a single block of limestone and appears to be a reconstruction. In

\footnotetext{
${ }^{45}$ This fixture has been heavily restored. For a photograph showing its configuration and state of preservation at the time of its excavation, see Cerulli Irelli 1977, pl. 26.3.

${ }^{46}$ For a photograph of this doorway, see Cerulli Irelli 1977, pl. 26.1.
}

the southeast corner of the room and projecting slightly into this doorway from the south is a counter constructed in rubble masonry $(1.3 \mathrm{~m}$ north-south $\mathrm{x}$ $0.5 \mathrm{~m}$ east-west) with two small steps at its northern end. ${ }^{45}$ There is a doorway at the western end of the room's south wall that opens onto the Caupona del Gladiatore at a point immediately inside the principal entrance ${ }^{46}$ This is fitted with a threshold consisting of a single block of Tufa di Nocera with a doorpost hole and step along its northern portion, evidence that it was once fitted with a door that opened into the facility and could perhaps be barred from this side. There is also a doorway in the southern part of the west wall that opens onto Room 2. Farther to the north along the west wall are two doorways, separated by a pillar, that open onto Room 4. The threshold currently fitted in the southern of these two doorways consists of two blocks of limestone and is a reconstruction. That currently fitted into the northern of the two doorways, consisting of two pieces of modern tile, is at a substantially higher level and is also a reconstruction. In the northeast corner of the room is a low basin constructed in rubble masonry and lined with cocciopesto $(3.0 \mathrm{~m}$ north-south $x 1.3 \mathrm{~m}$ east-west). A roughly circular pit (diam. 1.2-1.4 m, depth unknown) abuts the west wall of the basin. ${ }^{47}$ A low rubble masonry wall runs east-west from the exterior western wall of the low basin to the north-south wall that separates Room 1 from Room 4. The western end of the area to the north of this low wall has been built up to a level roughly even with the upper surface of the wall and has what appears to be a concrete paving. The pit is set into this built-up area. Whether this buildup represents reconstruction or is original is unclear.

Room 2 (2.9 m north-south x 3.3 m east-west) lies to the west of the southern portion of Room 1. There is a blocked doorway at the southern end of the west wall that once opened onto Room 5 .

Room 3 ( 1.4 m north-south $\times 3.5$ m east-west) is an east-west corridor occupying the northeast portion of the structure that provides access to Room 4 from the Via di Nocera. ${ }^{48}$ At its eastern end, where it opens onto the Via di Nocera, is a threshold consisting of a single block of Tufa di Nocera with circular cuttings (diam. 3 $\mathrm{cm}$ ) on its upper surface indicating that the doorway (I.20.3) was closed by a door or gate. Roughly halfway along the south wall is a niche (see fig. 10E) with an

\footnotetext{
${ }^{47}$ Cerulli Irelli $(1977,55)$ indicates that this pit was at least partially emptied in a probe excavated in 1973. For a photograph of this operation, see Cerulli Irelli 1977, pl. 27.4.

${ }^{48}$ For a photograph of the eastern end of this room, see Cerulli Irelli 1977, pl. 26.2.
} 
opening through the wall to the pit in the northern part of Room 1 slightly below floor level.

Room 4 (5.6 m north-south $\times 7.0$ m east-west), the open court, occupies the northwest part of the structure. It contains two updraft kilns, one in its northwest corner and the other in its southeast corner. Set against the eastern face of the west wall near its southern end is a stone cistern head (see fig. 10F) that provides access to a subfloor cistern of unknown size and configuration. Immured in the room's west wall is a downspout composed of Neo-Punic amphoras with their bases removed that channeled rainwater from the roof to the cistern.

Kiln 1, in the room's northwest corner, is the larger of the two (see fig. 10G).$^{49}$ It has a rectangular plan (1.6 m north-south $\times 2.1 \mathrm{~m}$ east-west), with its front facing to the east. The east side is constructed in mortared tile, the south side in mortared rubble, and the corner where the two meet in quoining of masonry blocks. ${ }^{50}$ The combustion (or furnace) chamber, in which the fuel was burned (internal measurements: 1.1 m north-south $\times 1.2 \mathrm{~m}$ east-west, ht. $0.9 \mathrm{~m}$ ) contains two north-south cross-walls. At the eastern side of the combustion chamber is a flue (lgth. $0.9 \mathrm{~m}$ east-west, wdth. $0.4 \mathrm{~m}$ north-south, ht. $0.65 \mathrm{~m}$ ). Its mouth consists of an arch constructed of mortared tiles. The firing chamber or kiln oven, in which the load of pottery to be fired was set, is situated directly atop the combustion chamber and has the same north-south and east-west internal dimensions. The perforated floor that separates the two chambers, through which rose the hot gasses from the combustion chamber, appears to have been constructed of a series of east-west running tiles laid end-to-end and held together by raw clay, which also covered the tiles. All four sides of the firing chamber are provided with a refractory lining consisting of a layer of bricks coated with a layer of clay. At the time of excavation, only the lining of the rear/west wall of the firing chamber was preserved to its full height, from which it is evident that the chamber was covered by an east-west vault that rose to a height about $1.25 \mathrm{~m}$ above the perforated floor, yielding an overall exterior height for the kiln of about $2.5 \mathrm{~m}$. A portion of this vault was preserved at its northern edge, revealing that it was constructed of three arches composed of interlocking ceramic vessels. As was the case with the flue, the door to the firing chamber (wdth. $0.4 \mathrm{~m}$, lgth. at least $0.5 \mathrm{~m}$, ht. ca. 1.0

\footnotetext{
${ }^{49}$ For a plan, two sections, elevation, axonometric reconstruction, and two photographs of this kiln, see Cerulli Irelli 1977, 70, fig. 3; 71, figs. 5-8, pls. 27.5, 27.6. For a sketch and four additional photographs of this kiln, see Pugliese Car-
}

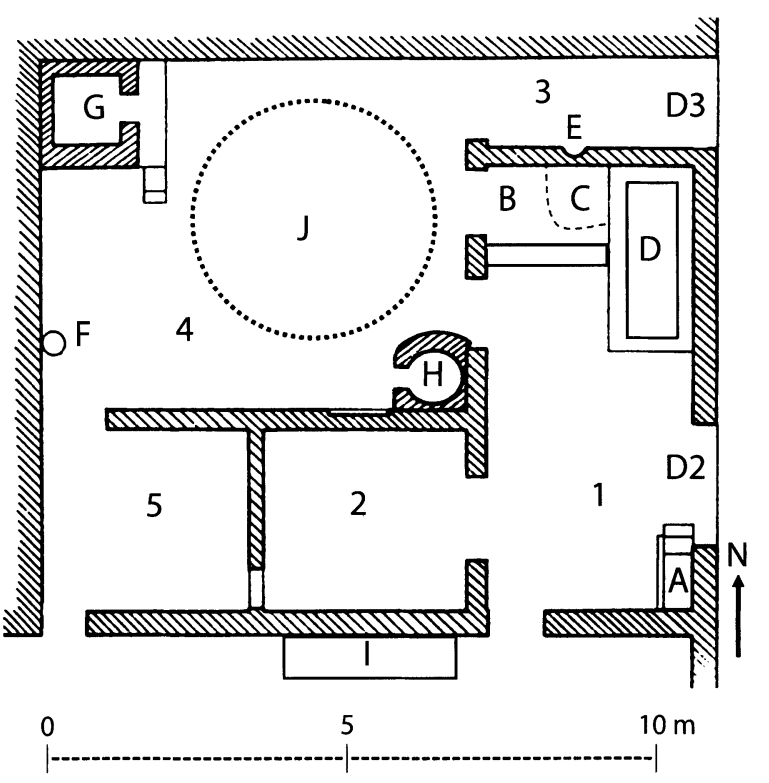

Fig. 10. Plan of Via di Nocera pottery production facility: $1-5$, Rooms 1-5; D2, D3, Doorways 2, 3; $A$, masonry counter; $B$, clay wedging area; $C$, clay mixing pit; $D$, levigation basin; $E$, niche; $F$, cistern head; $G$, Kiln 1; $H$, Kiln 2; I, stairway; J, circle with diameter of $4 \mathrm{~m}$, suggesting area required for orbiting of single-wheel type potter's wheel (modified from Cerulli Irelli 1977, figs. 1, 2).

$\mathrm{m})$ faces east. There is a square exhaust vent (10-15 $\mathrm{cm}$ on a side) near the top of the brick lining of the west/back wall of the combustion chamber for venting the heated gas and smoke from the kiln. The ends of several small terracotta tubes are visible in the lower part of the brick lining of the west and north chamber walls. These presumably passed completely through the chamber wall and were probably inserted by the potters to rectify problems with the draw. The front/ east wall of the firing chamber is set back about $0.5 \mathrm{~m}$ from the front/east wall of the flue, leaving a ledge immediately in front of the door to the firing chamber. Two large blocks of tuff are set against the eastern end of the south wall of the combustion chamber, creating a small set of stairs. This provided access to the ledge in front of the door to the firing chamber and would have facilitated loading and unloading the kiln. There are a few large fragments of tile set in clay at the bottom of the door to the firing chamber, indicating that it was closed by this method for firings. At the time of

\footnotetext{
ratelli and Baldassare 1990-2003, 2:1067-69, figs. 1-5.

${ }^{50}$ Kiln 1 has no north or west wall, as on these sides its lining was built directly against Room 2's north wall and west wall, respectively.
} 
excavation, there were two plaster reliefs of phalli on the front/east wall of the kiln immediately to the left of the flue mouth. ${ }^{51}$ These were presumably intended to provide protection against the various kinds of accidents that can occur during firings. ${ }^{52}$

Kiln 2, in the southeast corner of Room 4, is substantially smaller than Kiln 1 (see fig. 10H). It has an ovoid plan (major east-west axis: $1.3 \mathrm{~m}$; minor north-south axis: $1.1 \mathrm{~m}) .{ }^{53}$ The preserved height of the kiln, which may have been missing its upper portion at the time of its excavation, is about $1.25 \mathrm{~m}$. The west, east, and south sides are constructed in mortared tile, while the north side is constructed in mortared rubble and tile. ${ }^{54}$ The oval combustion chamber (major north-south axis: 1.0 $\mathrm{m}$; minor east-west axis: $0.8 \mathrm{~m}$; ht. $0.5 \mathrm{~m}$ ) has a single round pedestal support at its center. At its western side is a flue (lgth. $0.5 \mathrm{~m}$ east-west, wdth. $0.4 \mathrm{~m}$ north-south, ht. $0.4 \mathrm{~m}$ ) with a mouth consisting of an arch of mortared tiles. The firing chamber is situated directly atop the combustion chamber and has the same horizontal dimensions. The nature of the construction of the perforated floor is unclear. The firing chamber (ht. $0.6 \mathrm{~m}$ ) has a refractory lining composed of a layer of bricks coated with a layer of clay. It is unclear whether it was domed or open, requiring a temporary capping of large sherds or some similar material for firings. The door to the firing chamber (wdth. $0.4 \mathrm{~m}$, ht. at least $0.5 \mathrm{~m}$ ) faces west. At the time of excavation, there was a large fragment of tile set in what appears to be clay at the bottom of its right side, indicating that it was closed by this method for firings.

Room 5 (2.9 m north-south x 3.3 m east-west ) occupies the southwest portion of the facility. As already noted, there is a blocked doorway at the southern end of the east wall that once opened onto Room 2. There is also a doorway at the western end of its south wall opening onto the Caupona del Gladiatore near a masonry triclinium. Immediately to the east is a blocked window. Some of the concrete flooring had been removed and was stacked in the northeastern corner, possibly indicative of ongoing renovations. Cuttings

\footnotetext{
${ }^{51}$ These two plaster reliefs are no longer extant in situ and have been replaced by a single concrete phallus.

${ }^{52}$ For a stone relief of a phallus next to the flue mouth of a tile kiln at Pizzica, in the territory of Metaponto, see Carter 1979 , 60, fig. p.3.IVc; 63. For an amulet in worked bone in the form of a phallus recovered at the Black Gloss Ware production facility at Iesi, see Brecciaroli Taborelli 1998, 232, fig. 120.682; 233, no. 982.

${ }^{53}$ For a plan, two sections, elevation, axonometric reconstruction, and photograph of this kiln, see Cerulli Irelli 1977, 70, fig. 4; 72, figs. 9-12, pl. 27.7. For two additional photographs of this kiln, see Pugliese Carratelli and Baldassare 1990-2003, 2:1070, figs. 6, 7.
}

in the north wall suggest the presence of a bed there at one time.

There is a set of stone steps against the south wall of the pottery production facility/north wall of the Caupona del Gladiatore at a point opposite Room 2 (see fig. 10I). These constitute the lower part of a stairway that rose from west to east, providing access from the Caupona del Gladiatore either to the roof or to a mezzanine above Room 1 and perhaps also above Rooms 2,4 , and/or 3 .

Cerulli Irelli's description of this facility provides limited information regarding the portable objects that were preserved in it at the time of excavation. Some of this material is worth noting, however, as it elucidates certain aspects of the activities carried out there. Most importantly, materials were found inside Kilns 1 and 2, where it appears that they were placed either for storage or safe keeping. The combustion chamber of Kiln 1 contained 16 intact and eight fragmentary bivalve molds for the manufacture of singleand double-spouted lamps (fig. 11). ${ }^{55}$ These were manufactured from a mixture of plaster and marble dust and generally display a high degree of wear, suggesting substantial use. The firing chamber of Kiln 2 contained a pyramidal stack of 61 slipped, singlespouted, and double-spouted lamps in unused condition. Twenty-six of these were manufactured from 18 of the 24 molds found in Kiln 1. The combustion chamber of Kiln 2, in turn, held 123 examples of a vessel form generally identified as a dice cup and commonly referred to by archaeologists as a fritillus, ${ }^{56}$ with a disc base, a narrow body with near vertical walls, and a small, everted rim. Most of the examples from Kiln 2 stand about $13 \mathrm{~cm}$ tall. The one example pictured by Cerulli Irelli bears conspicuous wheel ridging on its exterior surface, indicating that it was thrown on a potter's wheel, presumably from the hump (fig. 12) ${ }^{57}$ Both the lamps and the dice cups are presumably products of the workshop on the premises. Compositional evidence suggests that the lamps and dice cups were manufactured in two distinct fabrics. ${ }^{58}$

\footnotetext{
${ }^{54}$ Kiln 2 has no south or east wall, as on these sides its lining was built directly against Room 2's south wall and east wall, respectively.

${ }^{55}$ For a description of these materials, including their identifications according to some of the more widely employed lamp classifications, see Cerulli Irelli 1977, 57-67, pls. 29-45; see also Ciarallo and De Carolis 1999, 174, no. 196.

${ }^{56}$ Cerulli Irelli 1977, 56. For this form, see Annecchino 1977b; Allison 2004, 58-9. For the use of the word fritillus in the Latin literary sources, see Hilgers 1969.

${ }^{57}$ Cerulli Irelli 1977, pl. 28.9.

${ }^{58}$ To be discussed in part 2 of this study, which will appear in a forthcoming issue of the AJA.
} 
Elsewhere, in Room 4, an unspecified number of Dressel 2-4 amphoras were found leaning against the wall near the cistern head. ${ }^{59}$ An intact Dressel 1B amphora was found inside the pit in the northern part of Room $1 .^{60}$

While it is likely that some amount of waster pottery was present on the premises, no such material appears to have been documented during excavation. Consequently, all that can be said is that this workshop manufactured wheel-thrown dice cups and moldmade lamps. It presumably also manufactured various other wheel-thrown forms in the same fabric as the dice cups and perhaps also in the fabric of the lamps. Given the modest size of Kiln 1, the small size of Kiln 2, and the limited dimensions of the doors to their firing chambers, it seems unlikely that large vessels, such as amphoras, were manufactured here. ${ }^{61}$

The excellent state of preservation of the facility, however, affords an unparalleled opportunity to identify the spaces, fixtures, and implements used for specific production operations and to reconstruct the overall spatial organization of the various tasks carried out by the workshop that operated on the premises. It should be noted in this regard that some-perhaps several-of these operations may well have been carried out on the grounds of the Caupona del Gladiatore, and it cannot be excluded that one or more were undertaken at some other location.

By combining the evidence discussed above with general considerations regarding the technology of pottery production, it is possible to infer that the workshop performed at least 11 different operations (table 1):

1. Storage of raw materials. This would have involved the long- or short-term storage of varying amounts of potting clay, slip clay, fuel, water, and perhaps tempering material. Large amounts of potting clay and slip clay were possibly placed in long-term storage in some out-of-the-way place on the grounds of the Caupona del Gladiatore to weather. Smaller amounts of clay and temper could have been stored in Room 2, convenient for paste preparation in Room 1. A large amount of wood or other fuel was possibly stored on the grounds of the Caupona del Gladiatore for seasoning. A moderate amount of fuel was possibly stored in the open in Room 4 and/or under cover in Room 5. Fuel stored in these locations would have been ready to hand for firing operations. At least a portion of the water employed for paste

\footnotetext{
${ }^{59}$ These are presumably the examples of this class visible in Cerulli Irelli 1977, pl. 27.5; Pugliese Carratelli and Baldassare 1990-2003, 2:1067, fig. 1.
}

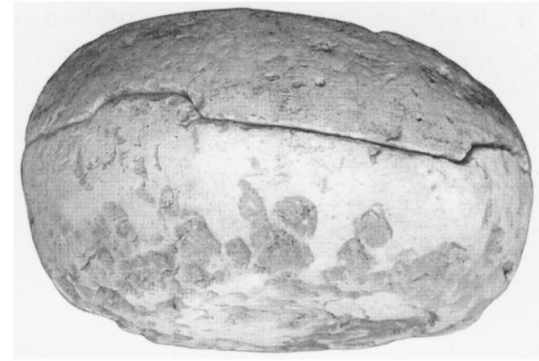

Fig. 11. Bivalve lamp mold recovered in the Via di Nocera pottery production facility (Cerulli Irelli 1977, pl. 30.13 [top]).

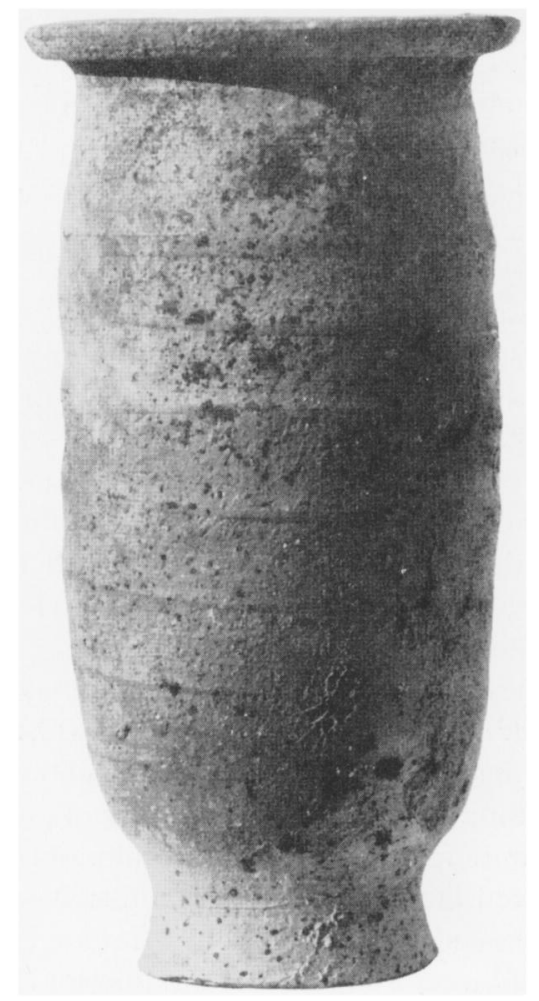

Fig. 12. Dice cup recovered in the Via di Nocera pottery production facility (Cerulli Irelli 1977, pl. 28.9).

preparation was collected from the roof, stored in the cistern underneath Room 4, and removed from the cistern via the cistern head in the southwest corner. The amphoras found near the cis-

\footnotetext{
${ }^{60}$ For this vessel, see Cerulli Irelli 1977, pl. 28.8.

${ }^{61}$ Ward-Perkins and Claridge (1978, 2:204) mistakenly assert that amphoras were manufactured at this facility.
} 
Table 1. Workshop Operations and Their Locations at Via di Nocera Pottery Production Facility.

\begin{tabular}{|c|c|c|c|c|c|c|c|c|c|c|}
\hline Activity/Use & $\begin{array}{c}\text { Room } \\
1\end{array}$ & $\begin{array}{l}\text { Room } \\
2\end{array}$ & $\begin{array}{c}\text { Room } \\
3\end{array}$ & $\begin{array}{c}\text { Room } \\
4^{\mathrm{a}}\end{array}$ & $\begin{array}{c}\text { Room } \\
5\end{array}$ & Mezzanine $^{b}$ & $\begin{array}{c}\text { Flat } \\
\text { Roof }^{\text {a,b }}\end{array}$ & $\begin{array}{l}\text { Osteria del } \\
\text { Gladiatore }\end{array}$ & Sidewalk $^{\mathrm{b}}$ & Off-Site \\
\hline Clay storage & - & $?$ & - & - & - & - & - & $?$ & - & - \\
\hline Fuel storage & - & - & - & $?$ & $?$ & - & - & $?$ & - & - \\
\hline Water storage & - & - & - & $\mathrm{x}$ & - & - & - & - & - & - \\
\hline $\begin{array}{l}\text { Paste } \\
\text { preparation }\end{array}$ & $\mathrm{x}$ & - & - & - & - & - & - & - & - & - \\
\hline $\begin{array}{l}\text { Slip } \\
\text { preparation }\end{array}$ & $\mathrm{x}$ & - & - & $?$ & - & - & $?$ & $?$ & - & - \\
\hline Mold forming & $?$ & - & - & $?$ & - & - & $?$ & $?$ & - & - \\
\hline Throwing & $?$ & - & - & $?$ & - & - & $?$ & $?$ & - & - \\
\hline Drying & - & $?$ & - & $?$ & $?$ & $?$ & $?$ & $?$ & - & - \\
\hline Slipping & - & $?$ & - & $?$ & $?$ & $?$ & $?$ & $?$ & - & - \\
\hline Firing & - & - & - & $\mathrm{x}$ & - & - & - & - & - & - \\
\hline Vessel storage & - & $?$ & - & - & $?$ & $?$ & - & - & - & - \\
\hline Vessel display & $\mathrm{x}$ & - & - & - & - & - & - & - & $?$ & - \\
\hline $\begin{array}{l}\text { Discarding of } \\
\text { refuse }\end{array}$ & - & - & - & - & - & - & - & $?$ & - & $\mathrm{x}$ \\
\hline Residence & - & $?$ & - & - & $\mathrm{x}$ & $?$ & - & - & - & $?$ \\
\hline
\end{tabular}

$\mathrm{x}=$ certain $/$ probable use; $?=$ possible use

${ }^{\mathrm{a}}$ unroofed

${ }^{\mathrm{b}}$ conjectured space

tern head and perhaps also the amphora found in the pit in Room 1 were probably employed for retrieving water and carrying it to Room 1 for paste preparation.

2. Paste preparation. This would have involved the hydrating and mixing and perhaps also the levigating of potting clay, the mixing of two or more potting clays, and/or the mixing of potting clay and temper. Once a quantity of paste had been mixed, larger or smaller amounts of it would have been wedged on a clean, hard surface. Paste preparation certainly occurred in Room 1 . The basin in the northeast corner was probably employed for the levigating of potting clay. The pit in the north-central part of the room was probably used for hydrating and mixing potting clay and, if required, the mixing of two or more potting clays and/or the mixing of potting clay and temper. ${ }^{62}$ In this process, the materials would have been placed in the pit along with a suitable amount of water and allowed to stand; a worker would then

\footnotetext{
${ }^{62}$ Cerulli Irelli $(1977,54-5)$ believed that this pit was a fossa biologica (cesspit).

${ }^{63}$ Cerulli Irelli $(1977,54-5)$ believed that the niche in the south wall of Room 3 was a urinal; the urine discharged into it would have emptied into the putative cesspit in the north-
}

have climbed into the pit, placed his hands along its edge for leverage and balance, and trod the mixture until it reached the desired consistency. Potting clay, temper, and water could have been introduced into the pit directly from the south or west, while water also could have been introduced by being poured into the niche in the south wall of Room $3 .^{63}$ The latter would have been convenient when it was necessary to obtain water offsite, as may well have been the case during the summer months. Large quantities of paste could have been wedged in the paved area to the north of the low east-west wall in the northwest part of the room, if this feature is original. ${ }^{64}$ Paste could have been transferred directly to this area from the pit. Small amounts of paste were probably wedged on the masonry counter in the southeast corner of the room.

3. Slip preparation. This would have involved dumping dried and pulverized slip clay into a basin of water, with the finer fraction going into suspen-

\footnotetext{
central part of Room 1.

${ }^{64}$ Cerulli Irelli $(1977,55)$ believed that this area was occupied by a wooden staircase that ran west-east from the northernmost door in the west wall of Room 1 up to a mezzanine, adducing as evidence the threshold block in the doorway and
} 
sion while the coarser fraction settled to the bottom. The suspension would have been decanted into some other receptacle and left to standprobably in direct sunlight-until the bulk of the water had evaporated, leaving behind a slurry composed primarily of clay minerals that was suitable for use as slip. The fractioning of slip clay was very likely carried out in the low basin in Room 1 . Portable basins containing the suspension were probably left to stand in one or more open spaces, including possibly Room 4, the Caupona del Gladiatore, and the possible flat roof.

4. Mold-forming of lamps. This would have involved rolling out sheets of clay, cutting these to the appropriate size, and then pressing these into molds. This operation could have been carried out in any area that offered adequate light and contained a work surface. The most suitable spaces appear to be Room 1, with its masonry counter and broad doorway to the street, or the various unroofed spaces that could have been furnished with wooden tables, including Room 4 , the Caupona del Gladiatore, and the possible flat roof.

5. Throwing of vessels. This would have required a potter's wheel and space around the wheel to set newly formed vessels. The wheel was presumably a single-wheel type similar to those depicted in the frescoes discussed above. While the facility produced no evidence for a potter's wheel, this is not surprising, since a small item such as a pivot stone might well have escaped the attention of the excavators, while the other parts of the device may have been of wood. It seems probable that throwing was carried out in two or more different spaces, which between them probably included at least one covered space, so that it was possible to throw during both the rainy months (roughly November-March) and the sunniest part of the year (roughly July-August), and one space that offered an unobstructed area measuring at least $4 \mathrm{~m}$ across, so that it was possible for the potter to orbit the wheel as he worked. Room 1, the largest and best lit of the roofed spaces, is the most suitable space of the first kind. Room 4, the Caupona del Gladiatore, and the possible flat roof are all suitable spaces of the second kind.

6. Drying of newly formed and newly slipped vessels. This would have involved setting out newly formed vessels to dry for a few days to several weeks, ideally in a space where they would have been protected from damage and would not have

the low east-west wall, which she believed served to support this structure. obstructed other operations. While vessels could usually be set out to dry in an open space, there would also have been need of a covered area for vessels that needed to dry slowly and/or vessels formed during the rainy months. Room 4, the Caupona del Gladiatore, and the possible flat roof would all have been suitable. Rooms 2 and 5 and the possible mezzanine could also have been used. The drying of slipped vessels would most likely have been carried out in the same spaces as those used for drying newly formed vessels.

7. Slipping of dried vessels. This would have involved dipping dried vessels into a basin of slip, pouring slip into dried vessels, and/or painting slip onto dried vessels. These tasks could have been carried out in almost any space, although it would have been advantageous to do this at or near the drying location where they could be left while the slip dried. Rooms 2-5, the possible mezzanine, the possible flat roof, and the Caupona del Gladiatore would have been suitable for this operation.

8. Firing of vessels. This operation was carried out in Room 4 using Kilns 1 and 2.

9. Storage of completed vessels. Completed vessels would have been stored for shorter or longer periods, ideally in a space where they would have been secure from theft or damage and would not have obstructed other operations. Rooms 2 and 5 and the possible mezzanine would have been suitable for this operation.

10. Display of completed vessels. This probably involved setting out representative examples of various vessel forms where they could be examined by potential wholesale and/or retail buyers. The northern end of the masonry counter in Room 1 was probably employed for this purpose; the sidewalk along the Via di Nocera in front of the facility may also have been used for this.

11. Collection/removal of refuse. Various kinds of production-related refuse, including kiln ash, waster pottery, ruined kiln furniture, and structural debris from the kilns would have been collected and disposed of somewhere off-site. Some or all of the kiln ash and other kinds of refuse generated in and around the kilns may have been spread over the surface of the vineyard in the Caupona del Gladiatore as fertilizer. The remaining waste was likely hauled down the Via di Nocera and out through the Porta di Nocera and then dumped onto refuse middens that likely existed beyond the gate. ${ }^{65}$

\footnotetext{
${ }^{65}$ For the discard of refuse outside the walls of Pompeii, see Peña 2007, 279-82.
} 
Some or all of the workforce may have lived on the premises. The presence of a cutting for a bed in Room 5 suggests that it served at least in part as a residential space. Room 2 and the possible mezzanine may also have served for this purpose.

It is impossible to infer how many persons labored at this facility at any one time, the identities and social status of these people, or their relationship to the person or persons who owned it. One can speculate, however, that the workshop's operations might have involved the labor of as few as two or three persons if the various tasks were undertaken serially or the labor of as many as six to eight persons if several of these were carried out concurrently, particularly if one or more were undertaken on the grounds of the Caupona del Gladiatore. It seems possible that part or all of the workforce divided its time between the workshop's operations and those associated with the vineyard and dining facility on the grounds of the Caupona del Gladiatore. The overseer of operations at both facilities may have lived in Room 5, as this enjoyed ready access to both properties. One might also conjecture that the Via di Nocera pottery production facility and the Caupona del Gladiatore were the property of a single person, and that the operations carried out in both spaces were closely linked.

The fact that the workshop had two kilns of different sizes and configurations meant that it could operate more efficiently than it could have with a single kiln. Not only did this permit the workshop to fire both small and large lots of vessels in a kiln of appropriate size, it was also possible to fire on an almost continuous basis when necessary, with the workers preparing one kiln for firing while the other was being fired, cooling, or undergoing maintenance.

Cerulli Irelli, noting that completed vessels and molds were being stored in the two kilns when the town was destroyed, concluded that the workshop was not active at that time. ${ }^{66}$ While it is possible that workers placed the molds and vessels inside the kilns to protect them from the eruption, the fact that the lamps recovered inside the firing chamber of Kiln 2 were found carefully stacked in a pyramidal arrangement suggests that this is probably not the case.

\footnotetext{
${ }^{66}$ Cerulli Irelli 1977, 56 . Her suggestion is supported by the fact that an amphora was found in the clay-mixing pit in Room 1 and that the concrete pavement in Room 5 was in the process of being restored at the time of the eruption of Mount Vesuvius.

${ }^{67}$ Stefani 2006

${ }^{68}$ For the history of the excavation of the structures belonging to this facility, see Kockel and Weber 1983, 70-2.

${ }^{69}$ Kockel and Weber 1983; see also Annecchino 1977a, 106;
}

Although the inference that the workshop was not active at the time of Pompeii's destruction may well be correct, ethnographic studies of traditional potters have shown that many workshops fire only infrequently or on a fairly long cycle, in some cases no more than once per month. The eruption may have occurred when the workshop was between firings. If operations were suspended, and one assumes the traditionally accepted date of 24-25 August 79 C.E. for the eruption, it may be that the workshop had suspended firing during the hottest part of the year. Alternatively, if one assumes that the eruption occurred during late October 79 C.E., as Stefani has recently argued, ${ }^{67}$ the workshop may have suspended operations so that the workers could help harvest and press the grapes from the vineyard of the Caupona del Gladiatore.

It may be significant that the group of finished vessels found inside Kiln 2 consisted of lamps and dice cups. Perhaps vessels belonging to these two forms were regularly consumed in connection with the dining activities carried out in the Caupona del Gladiatore or employed as grave goods in the necropolis outside the Porta di Nocera, and the workshop made certain to build up a small stock of both prior to suspending operations for the season so that it could continue to satisfy the ongoing demand for these items.

The Via Superior Pottery Production Facility. The Via Superior pottery production facility is situated on the Via Superior, about $150 \mathrm{~m}$ outside the Porta di Ercolano (see fig. 1 [8]). Excavations undertaken in this area first in 1838 and then again in or somewhat before 1875 revealed structures that appear to constitute part of a pottery production facility. ${ }^{68}$ The structures in question, which have never been published in detail, occupy the northwest end of a northwest-southeast oriented commercial strip building that runs along the northeast side of the Via Superior, backing up against the Villa delle Colonne a Mosaico. Kockel and Weber, in a 1983 article concerned mainly with the Villa delle Colonne a Mosaico, presented a plan, reconstruction, and brief description of this structure, henceforth referred to as the Strip Building. ${ }^{69}$

The Strip Building measures about $86 \mathrm{~m}$ long northwest-southeast and about $18 \mathrm{~m}$ deep northeast-south-

Kockel 1983, 8, 161; Gasperetti 1996, 57; Pappalardo 2001, $153-54$. Kockel $(1983,212)$ presents a plan of the Strip Building that, though less detailed than the one presented in Kockel and Weber (1983), is somewhat more informative in that it also includes the structures in the area around the building. The Pompeii Via Consolare Study Project completed a new plan of this area in 2005/2006 (see Edwards and Anderson 2007). 
west (fig. 13).$^{70}$ Kockel and Weber date its construction to ca. $150-100$ B.C.E. ${ }^{71}$ It is cut into a low hill slope, forming a kind of terrace between the Via Superior to the southwest and the somewhat higher Villa delle Colonne a Mosaico to the northeast. The building consists of a row of 14 generally identical two-story, fourroom ranges (Ranges 16-29 on Kockel and Weber's plan) - each with a pair of rooms on the lower level and a pair of rooms on the upper level-fronted by a continuous arcade. The lower pair of rooms consists of a front room with a broad (wdth. $2.5 \mathrm{~m}$ ) doorway opening onto the arcade and an inner room roofed with a transverse barrel vault and connected to the front room by a doorway in their common wall. The upper pair consists of a room set immediately above and another behind (to the northeast of) the lowerlevel inner room. Little of the two upper-level rooms has been documented, and it is unclear whether these were connected with the two lower-level rooms or constituted an independent unit that opened to the rear of the building. There are two or three stone stairs preserved in the front right-hand/south corner of the lower-level front room in two of the ranges (Ranges $19,20)$, indicating that in these cases-and perhaps in several or even all of them-this room contained a staircase that ran along its right-hand wall. ${ }^{72}$ This presumably provided access to the two upper-level rooms and perhaps also to a mezzanine located directly above the lower-level front room. Inserted between Ranges 20 and 21 is a small fountain room.

At its southeast end, the Strip Building terminates in a ramped corridor that leads back from the arcade to the Villa delle Colonne a Mosaico. At its opposite/ northwest end, the building originally had a room of some kind that balanced this corridor. This room was not, however, a corridor similar to the one at the southeast end of the building, as it is closed at its northeast end. Whatever its original configuration and function, this room was eventually converted into a long, narrow enclosed space (Range 30 ) by blocking both the final arch in the arcade and an arch in the southeast wall that opened onto the area covered by the arcade. This room is connected to the lower-level front room in the last range of rooms by a doorway that was perhaps created when the two arches were blocked.

The structures that constitute the exposed part of the Via Superior pottery production facility consist of the

\footnotetext{
${ }^{70}$ Kockel and Weber 1983, 55-6, 75-9.

${ }^{71}$ Kockel and Weber 1983, 62-3.

${ }^{72}$ Ranges 16 and 21 may also preserve a stone footing for a stairway in their south corner. The plan of Pompeii published in Eschebach (1970) indicates a staircase along the right-
}

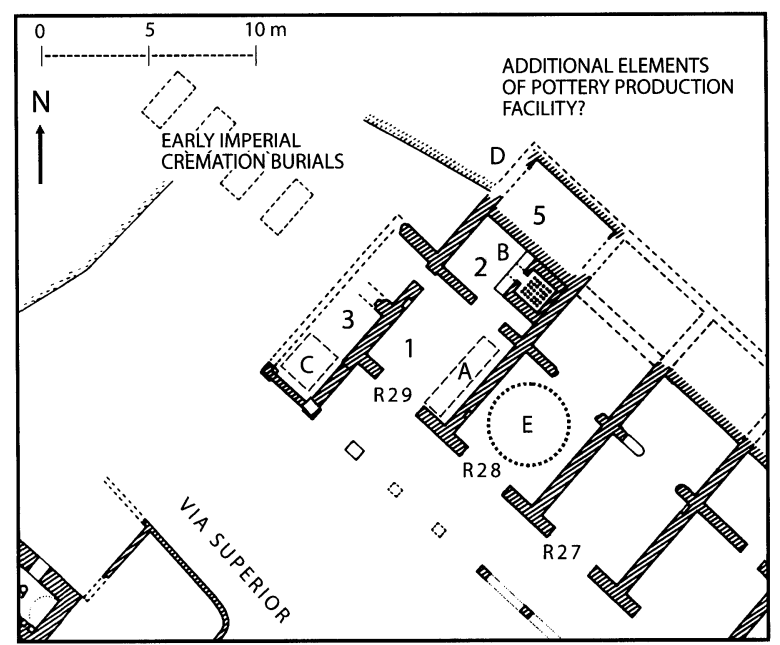

Fig. 13. Plan of Via Superior pottery production facility: $R 27-$ 29, Ranges 27-29; 1-3, 5, Rooms 1-3, 5; A, possible stairway; $B$, Kiln 1; $C$, possible location of Kiln 2; $D$, possible doorway; $E$, circle with diameter of $4 \mathrm{~m}$, suggesting area required for orbiting of single-wheel type potter's wheel (modified from Kockel 1983, 212 [plan]).

four rooms of the final range of rooms on the northwest end of the building (Range 29) and the long, narrow room created in the flanking element at its northwest end by the blocking of the two arches (Range 30). These are here termed Rooms 1-5. The facility may also have had a mezzanine above the lower-level front room and a flat roof, both of which could have been used for pottery production operations. ${ }^{73}$

Room 1 (5 m northwest-southeast x $5 \mathrm{~m}$ northeast-southwest), the lower-level front room opens onto the arcade and contains a small lararium niche in its left/northwest wall. There is a broad stone embedded in the floor in its southeastern corner that may have served as the foundation for a stairway (see fig. 13A) ascending to the northeast.

Room 2 (5.0 m northwest-southeast x $3.2 \mathrm{~m}$ northeast-southwest), the lower-level inner room, contains an updraft kiln, here termed Kiln 1 (see fig. 13B), set into its right rear/east corner. ${ }^{74}$ This has a square plan and is similar in its general configuration to Kiln 1 in the Via di Nocera facility. The combustion chamber and flue (external dimensions: lgth. $2.5 \mathrm{~m}$ on a side, ht. $1.0 \mathrm{~m}$ ) are constructed in mortared rubble. The

\footnotetext{
hand wall in all 14 ranges.

${ }^{73}$ Kockel and Weber (1983, fig. 2) restore the Strip Building's roof as a flat roof.

${ }^{74}$ For an elevation, plan, and two sections of this kiln, see Kockel and Weber 1983, 78, pls. 8-11.
} 
mouth of the flue, which opens to the northwest, consists of flanking piers in mortared tile that support an arch in mortared tile. The firing chamber (external dimensions: $2.0 \mathrm{~m}$ northwest-southeast $\mathrm{x} 2.5 \mathrm{~m}$ northeast-southwest) is constructed in mortared tile, with quoining in small blocks of tuff at its northwest corner. The perforated floor appears to be supported by two arches that spring from the side walls of the combustion chamber rather than by cross-walls. While at the time of excavation in 1838 the roof of the firing chamber was largely intact, this has since collapsed. It consisted of a northwest-southeast barrel vault built around an unknown number of arches constructed of interlocking ceramic vessels. There is a square exhaust element ( $30 \mathrm{~cm}$ on a side) in the upper part of the back wall. This element continues into Room 4 above, where it consists of a square opus incertum chimney that must have vented through the roof above this room. The chamber door (wdth. $0.5 \mathrm{~m}$, ht. $1.5 \mathrm{~m}$ ), located on its northwest side, was arched. Beside and above this door are five apertures consisting of terracotta tubes that pass through the chamber wall. Two of these apertures, which were presumably used to regulate the kiln's draw and/or to monitor the firing, were found blocked by a mixture of clay and sherds. As with Kiln 1 in the Via di Nocera facility, there is a small (wdth. $50 \mathrm{~cm}$ ) ledge in front of the door corresponding to the length of the flue.

Room 3 (2.6 m northwest-southeast x $8.0 \mathrm{~m}$ northeast-southwest), the long, narrow room created from the flanking element along the northwest side of the building, is very poorly documented. It appears to have been only partially excavated and is today partially reburied and overrun with vegetation. Somewhere in this room was an updraft kiln, here termed Kiln 2 (see fig. 13C), that is no longer visible. ${ }^{75}$ This fixture (external dimensions: 2 x $2 \mathrm{~m}$ ) was constructed of brick, with the door to its firing chamber (wdth. $0.3 \mathrm{~m}$, ht. $1.1 \mathrm{~m}$ ) at least partially preserved. ${ }^{76}$ As the width of the kiln is only slightly less than that of the room, and the room was apparently entered at its northeast end from Room 1 , the kiln must have occupied the southwest end of the room, with both the mouth of its flue and the door of its firing chamber facing to the northeast.

Room 4 (5.0 m northwest-southeast x $3.2 \mathrm{~m}$ northeast-southwest), the room above Room 2 , is poorly documented. Its northwest wall retains the lower portion of a barrel vaulted roof springing from the northwest and

\footnotetext{
${ }^{75}$ Kockel and Weber $(1983,79)$ state that the existence of this second kiln is uncertain.

${ }^{76}$ Annecchino 1977a, 106.

${ }^{77}$ Kockel and Weber 1983, 56, 77.
}

oriented at a right angle to the barrel vault that covered Room 2. Its southeast wall retains the edge of a vault springing from the northeast, apparently the remains of a vaulted niche. The northeast corner is taken up by the chimney for Kiln 1 . The presence of concrete paving on the upper surface of the vault in Room 2 demonstrates that Room 4 had a concrete floor.

Room 5 (5.0 m northwest-southeast $x 3.4 \mathrm{~m}$ northeast-southwest), the room on the upper level to the rear, is also poorly documented, and its northwest and southeast walls have been reburied. Since there is a blocked doorway that once opened onto the ramp corridor at the opposite end of the Strip Building, it seems possible that there was a balancing doorway in the northwest wall of Room 5 that opened onto the area behind the north corner of the building.

The apparent late date of the conversion of the flanking element at the northwest end of the building to Room 3 and the fact that Kiln 1 appears to cover patching in the wall of Room 2 combine to suggest that the pottery production facility was inserted into these rooms fairly late in the life of the building, perhaps following the earthquake of 62 C.E. ${ }^{77}$

There is only limited and discordant information regarding the artifacts excavated from the facility. According to Gasperetti, the retrobottega, presumably Room 2, contained 382 vessels of the same form. ${ }^{78}$ Kockel and Weber, in contrast, state that 92 pots identified as pignatte (cookpots) and pignattini (small cookpots) were found in this room. ${ }^{79}$ Elsewhere, Annecchino states that 34 vessels that she terms marmitte (cooking vessels) were found in Room 3 next to Kiln 2 , with additional pottery found in a room adjacent to it, presumably meaning Room $1 .^{80}$ This evidence suggests that this workshop may have specialized in making cookwares.

Despite the fragmentary nature of the evidence, it is possible to identify the spaces and fixtures employed for specific production operations and to reconstruct in a general way the overall spatial organization of the various tasks carried out by the workshop. This workshop must have performed at least eight different operations (table 2):

1. Storage of raw materials. Moderate amounts of potting clay were possibly stored in Rooms 4 and 5 . Moderate amounts of fuel were possibly stored in Rooms 1, 2, and 3, and in the space under the arcade. Although water could have been obtained

\footnotetext{
${ }^{78}$ Gasperetti 1996, 54.

${ }^{79}$ Kockel and Weber 1983, 79.

${ }^{80}$ Annecchino 1977a, 106.
} 
Table 2. Workshop Operations and Their Locations at Via Superior Pottery Production Facility.

\begin{tabular}{|c|c|c|c|c|c|c|c|c|c|}
\hline Activity/Use & $\begin{array}{c}\text { Room } \\
1\end{array}$ & $\begin{array}{c}\text { Room } \\
2\end{array}$ & $\begin{array}{c}\text { Room } \\
3\end{array}$ & $\begin{array}{c}\text { Room } \\
4\end{array}$ & $\begin{array}{c}\text { Room } \\
5\end{array}$ & Mezzanine $^{a}$ & $\begin{array}{c}\text { Flat } \\
\text { Roof }^{a, b}\end{array}$ & Arcade & Off-Site \\
\hline Clay storage & - & - & - & $?$ & $?$ & - & - & - & - \\
\hline Fuel storage & $?$ & $?$ & $?$ & - & - & - & - & $?$ & - \\
\hline Water storage & - & - & - & - & - & - & - & - & - \\
\hline Paste preparation & - & - & - & - & - & - & - & - & - \\
\hline Throwing & $?$ & - & - & - & - & - & $?$ & - & - \\
\hline Drying & $?$ & - & - & $?$ & $?$ & $?$ & $?$ & - & - \\
\hline Firing & - & $\mathrm{x}$ & $\mathrm{x}$ & - & - & - & - & - & - \\
\hline Vessel storage & $?$ & $\mathrm{x}$ & $\mathrm{x}$ & $?$ & $?$ & $?$ & - & - & - \\
\hline Vessel display & $?$ & - & - & - & - & - & - & $?$ & - \\
\hline $\begin{array}{l}\text { Discarding of } \\
\text { refuse }\end{array}$ & - & - & - & - & - & - & - & - & $\mathrm{x}$ \\
\hline Residence & - & - & - & - & - & $?$ & - & - & $?$ \\
\hline
\end{tabular}

$\mathrm{x}=$ certain/probable use; ? = possible use

${ }^{\text {a }}$ conjectured space

${ }^{b}$ unroofed

from the fountain room between Ranges 20 and 21 , there is no installation on the premises for storing water.

2. Paste preparation. None of the spaces contains a pit or basin that could have been employed for the hydrating and mixing of clay.

3. Throwing of vessels. A potter could have operated a single-wheel type wheel in Room 1, although he would have been able to orbit the wheel only if nothing else of any substantial size was stored in the room. The conjectured flat roof would have been large enough for a potter to orbit a wheel.

4. Drying of newly formed vessels. Vessels were possibly dried in Rooms 1, 4, and 5, the possible mezzanine, and on the possible flat roof.

5. Firing of dried vessels. Firing was carried out in Room 2 using Kiln 1 and in Room 3 using Kiln 2.

6. Storage of completed vessels. Completed vessels were stored in Rooms 2 and 3, and possibly in Rooms 1, 4, and 5, and the possible mezzanine.

7. Display of completed vessels. Completed vessels were probably displayed for sale in Room 1 and in the area under the arcade.

\footnotetext{
${ }^{81}$ Little information is available regarding the activities that were carried out in the other four-room ranges in the Strip Building; see Kockel and Weber 1983, 75-9. The front room in the first range on the southeast (Range 16) contains a counter typical of popinae (wine bars) and presumably func-
}

8. Collection/discard of refuse. Kiln ash and other refuse produced in and around Kilns 1 and 2 must have been carried out through the exterior doorway of Room 1 and were probably discarded nearby.

Some or all of the workforce may have resided in the possible mezzanine.

On the basis of these observations, it appears unlikely that the five rooms identified as belonging to the facility constituted all of it. While it seems possible that some of the operations not accounted for with certainty, such as the storage of potting clay and the throwing of vessels, were carried out in one or more of the other four-room ranges in the Strip Building, ${ }^{81}$ others, specifically paste preparation and water storage, could not have been accommodated in any of these spaces. Although it is tempting to posit the zone to the west and immediately beyond the end of the Strip Building as a possible location for some of these other elements, this area contained several Early Imperial cremation burials and would have been accessible to passersby on the Via Superior (see fig. 13) and thus can probably be excluded. ${ }^{82}$ The most plausible suggestion is that any additional elements were located

tioned as such. Kockel (1983, 8 n. 67) states that a skeleton and the remains of a wagon were recovered in one of the fourroom ranges between 17 and 27 .

${ }^{82}$ For these burials, designated 31 and 32 on Kockel's plan of the area, see Kockel 1983, 161 
in the unexcavated, higher-lying area to the north and northwest of the Strip Building that is currently occupied by a tourist path and an orchard.

As was the case with the Via di Nocera facility, the fact that this facility possessed two kilns would have allowed the workshop to conduct firing operations on an almost continuous basis.

\section{OTHER FACILITIES SOMETIMES IDENTIFIED AS POTTERY PRODUCTION FACILITIES}

As previously noted, the Officina Vasaria di Nicanor may have been a venue for the manufacture of pottery (see fig. 1 [4]). ${ }^{83}$ This establishment, excavated during 1930-1935 and 1953-1955 and never published, is a large garden or vineyard with a dining facility, similar to the Caupona del Gladiatore (fig. 14). On the exterior of its south enclosure wall, immediately to either side of its principal doorway (II.3.9), were two frescoes: to the right, the fresco depicts Vulcan and a potter (discussed above), and to the left, a fresco depicts Minerva and Mercury, the protectors of craftsmen and commerce, respectively. ${ }^{84}$ It is reasonable to assume that these paintings referred to activities on the premises. While the excavations uncovered no fixtures relating to the manufacture of pottery anywhere on the grounds, it is interesting to note that the relationship between this property and the small structure of unknown function adjacent to it (and that perhaps communicated with it) in the southeast corner of the insula (II.3.8) is generally similar to that between the Caupona del Gladiatore and the Via di Nocera pottery production facility.

Della Corte suggested that a pottery workshop did at some point operate here but that it moved to some other location prior to 79 C.E. (one can speculate to the Via Superior pottery production facility), perhaps as a consequence of the earthquake of 62 C.E., with the various fixtures relating to pottery manufacture dismantled at that time. ${ }^{85}$ While this seems reasonable, it may be that the establishment simply sold pottery that had been manufactured elsewhere. The inference that this facility was somehow involved with the manufacture and/or sale of pottery is strengthened by the fact that the two graffiti from the Praedia Iuliae Feli-

\footnotetext{
${ }^{83}$ For this facility, see Van der Poel et al. 1986, 44, 45; Pugliese Carratelli and Baldassare 1990-2003, 3:181-83; Eschebach 1993, 91-2. It receives its name from two or perhaps three electoral programmata painted on its exterior wall, one published as CIL 4 7570, that mention a certain Nicanor (Della Corte 1954, 322).

${ }^{84}$ For the latter fresco, now lost, see Della Corte 1954, 322.

${ }^{85}$ Della Corte 1954, 22. Maiuri (1939, 198; 1953-1954, 91), Annecchino (1977a, 107), Ward-Perkins and Claridge (1978,
}

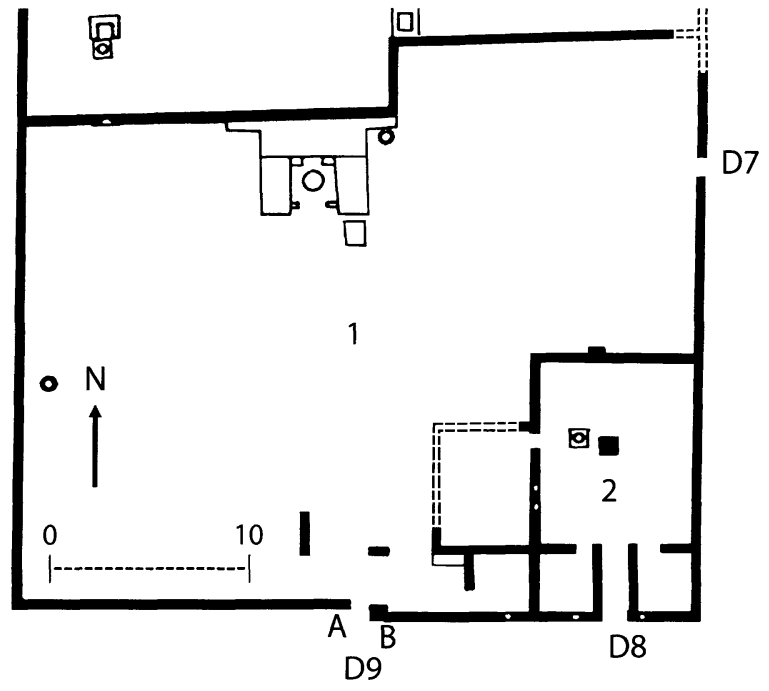

Fig. 14. Plan of southern portion of Regio II, Insula 3: 1, Officina Vasaria di Nicanor; 2, structure of uncertain function at II.3.8; $A$, location of fresco of Minerva and Mercury; $B$, location of fresco of Vulcan and potter (after Van der Poel et al. 1986, 45).

cis possibly referring to potters discussed above were scratched into the wall of an entry corridor (II.4.10) located almost directly across a narrow side street from the side entrance (II.3.7).

Two other structures at Pompeii are also sometimes identified as pottery production facilities, in both instances erroneously. The first of these, the Taberna del Vasaio Zosimo (III.4.1) (see fig. 1[9]) probably functioned as a facility for the distribution but not the production of pottery. ${ }^{86}$ The other, the Hospitium dei Pulcinella, as already noted, probably functioned as a hostel and/or restaurant in 79 C.E., although one of its rooms may have served as a pottery shop at some point prior to this. ${ }^{87}$

\section{CONCLUSION}

There is only a small amount of fragmentary evidence for the production of pottery at Pompeii during the pre-Roman period, and thus little can be said about pottery production in the town during this

2:20, no. 281), and Morel $(1984,264)$ all refer to this property as a pottery production facility.

${ }^{86}$ This facility is discussed in part 2, to appear in a forthcoming issue of the AJA. For its identification as a pottery production facility, see Della Corte 1954, 298; Annecchino 1977a, 107.

${ }^{87}$ For the identification of this facility as a pottery production facility, see Maiuri 1953-1954; Ciarallo and De Carolis 1999, 164. 
period. One workshop operated in the older, more densely developed southwest quarter of the town prior to the middle of the second century B.C.E. and perhaps beginning as early as the late fourth century B.C.E., engaging in mixed production that included Black Gloss Ware and commonware.$^{88}$ There may have been a workshop that produced Megarian bowls active during the second half of the second century B.C.E. or the first two decades of the first century B.C.E. somewhere in the vicinity of the Porta di Stabia.

Not surprisingly, there is substantially more evidence for the production of pottery at Pompeii during the Roman period. Two frescoes depicting potters at work, one from the Officina Vasaria di Nicanor, the other from the Hospitium dei Pulcinella, strongly suggest that the potters active in the town during this period employed the single-wheel type wheel for the throwing of pottery. This is a point of considerable interest, since wheels of this kind could be easily dismantled and moved, raising the possibility that Pompeian potters and perhaps Roman potters more generally enjoyed considerable flexibility in the use of the space available to them at their production facilities.

Three graffiti provide some insight into the social status and degree of specialization of potters. The first, a praecocturam graffito on a relief vessel, indicates that in at least one case a potter was of servile status. Two graffiti scratched into a wall at the Praedia Iuliae Felicis, in turn, raise the possibility that some potters specialized in the manufacture of particular vessel forms, specifically jugs or amphoras and plates. The fact that the rich epigraphic corpus from Pompeii contains no other kinds of texts that refer to potters (e.g., epitaphs) accords with the evidence for the rest of Roman Italy, where attestations of potters in texts other than stamps and graffiti on pottery are extremely rare. ${ }^{89}$

Excavation has uncovered the remains of two pottery production facilities where workshops were active during the period immediately prior to the town's destruction. The Via di Nocera pottery production facility was engaged in the manufacture of moldmade lamps and wheel-thrown pottery, including dice cups. The excellent state of preservation of the remains combined with the fact that it was excavated in its entirety down to 79 C.E. ground level allow the various tasks involved in pottery manufacture to be attributed to specific spaces with a higher degree of specificity than

\footnotetext{
${ }^{88}$ Mixed production consisting of Black Gloss Ware and commonware is also attested for the second century B.C.E. at the rural pottery production site at Chiusi-Marcianella (see Pucci and Mascione 2003).

${ }^{89}$ Delplace 1978, 56.

${ }^{90}$ Peacock 1982, 9, 25-38, 90-9.
}

is possible for probably any other pottery production facility known from the Roman world. Even so, much is still speculative. This is due to the possibility that some of the operations were carried out in the adjacent Caupona del Gladiatore or some third location; the lack of evidence for the upper parts of the building; the fact that many of the operations did not require installations likely to be preserved; and the paucity of information regarding the portable objects or refuse features likely present in the facility at the time of excavation. It seems probable, however, that most of the spaces served for multiple operations, while many tasks, including throwing, were carried out in more than one space.

The workshop in the Via Superior pottery production facility produced cookwares and may have specialized in the manufacture of these. Because of the poor quality of the information available about this facility, and that it appears to have included elements situated beyond the boundaries of the excavated area, it is possible to reconstruct production operations in only a generalized way.

While it is difficult to gauge the size of the workforce associated with either of these workshops, the size of the production facilities suggests that this was not very large, and we can probably characterize both establishments as examples of Peacock's "individual workshops" mode of pottery production. ${ }^{90}$ Neither would appear to have had enough space to support the simultaneous operation of four wheels, as is perhaps depicted in the fresco from the Hospitium dei Pulcinella. Although it seems possible that these two establishments (perhaps along with a third operating at the Officina Vasaria di Nicanor) provided Roman-period Pompeii with all its locally manufactured cookwares, commonwares, and lamps, with one perhaps specializing in cookwares and the other in commonwares and lamps, it cannot be excluded that there was at least one more pottery production facility located either in the unexcavated parts of Pompeii or somewhere outside the town, either in the immediate extra-urban zone or further afield. ${ }^{91}$ There must surely have been extramural facilities for the production of amphoras, opus doliare, and architectural ceramics.

This evidence suggests that there was a shift in the locus of pottery production at Pompeii from the preRoman to the Roman period, with this activity being

\footnotetext{
${ }^{91}$ The possibility that all the locally manufactured commonwares in use at Pompeii during the decades preceding the town's destruction were produced by a single workshop might account for the notably high degree of homogeneity in both form and technique displayed by the corpus of commonwares from the town (see Gasperetti 1996, 56-7).
} 
relocated from the more densely developed southwest quarter of the town to less densely developed areas, including the southeast quarter of the town (where substantial areas were given over to vineyards and market gardens) and the extramural zone (where much of the land was either undeveloped or given over to burial facilities).$^{92}$ While it is difficult to document similar patterns for other towns and cities in pre-Roman and Roman Italy, settlements that have been subject to extensive excavation, such as Rome and Ostia, have yielded little evidence for pottery production facilities in their more densely developed intramural areas, while in some cases they have produced substantial evidence for the presence of establishments of this kind in their less densely developed intramural and extramural areas. ${ }^{93}$ The relegation of pottery manufacture to less densely developed areas would have both reduced the amount of noxious smoke to which a town's inhabitants were exposed and limited the fire hazard constituted by pottery production.

What still needs to be undertaken is a program of excavation aimed at establishing in greater detail the suite of forms manufactured at the Via di Nocera and the Via Superior pottery production facilities and their fabrics; this might improve our understanding of the roles played by the workshops in these two facilities in provisioning Pompeii with pottery. In the case of the former, excavation of the rammed-earth floor in Room 4 and/or the vineyard and adjacent areas in the Caupona del Gladiatore might well recover discarded waster pottery that would greatly increase our knowledge on these points. In the case of the latter, excavation in the area to the north and west of the Strip Building might well recover discarded waster pottery or structures and fixtures that formed part of the facility. ${ }^{94}$ Second, a study of the Officina Vasaria di Nicanor, including a study of the standing remains and perhaps also excavation, might help resolve the question of whether or not this was, in fact, a pottery production facility.

INSTITUTE FOR EUROPEAN AND MEDITERRANEAN
ARCHAEOLOGY
DEPARTMENT OF CLASSICS
THE UNIVERSITY AT BUFFALO,
STATE UNIVERSITY OF NEW YORK
BUFFALO, NEW YORK 14226
TPENA@ACSU.BUFFALO.EDU

\footnotetext{
${ }^{92}$ There is also evidence for the manufacture of architectural ceramics and terracotta figurines in the southwest quarter of the town during the pre-Roman period (Arthur 1986, 34-5; Placidi 2005).

${ }^{93}$ For pottery production facilities at Rome and Ostia, see
}

\author{
DEPARTMENT OF MODERN LANGUAGES AND \\ CLASSICS \\ ST. MARY'S UNIVERSITY \\ HALIFAX \\ NOVA SCOTIA B 3 H $3 \mathrm{C} 3$ \\ CANADA \\ MYLES.MCCALLUM@SMU.CA
}

\section{Works Cited}

Allison, P. 2004. Pompeian Households: An Analysis of Material Culture. UCLAMon 42. Los Angeles: University of California Press.

Annecchino, M. 1977a. "Suppellettile fittile da cucina di Pompei." In L'instrumentum domesticum diErcolano e Pompei, edited by A. Carandini, 105-20. Quaderni di Cultura Materiale 1. Rome: L'Erma di Bretschneider.

1977b. "Fritillus, un piccolo vaso di terracotta." CronPomp 3:198-213.

Arthur, P. 1986. "Problems of the Urbanization of Pompeii: Excavations 1980-1981." AntJ66:29-44.

Baldi, A. 1964. "Elementi di epigragia Pompeiana." Latomus 23:793-801.

Bon-Harper, S. 1999. "L'argilla nel contesto pompeiano." In Homo faber: Natura, scienza e tecnica nell'antica Pompei, edited by A. Ciarallo and E. De Carolis, 100-3. Milan: Electa.

Brecciaroli Taborelli, L. 1998. "Iesi: L'officina ceramica di Aesis (III sec. aC-I sec. dC).” NSc 7-8 (1996-1997):5-277.

Carter, J. 1979. "Rural Architecture and Ceramic Industry at Metaponto, Italy." In Roman Brick and Tile: Studies in Manufacture, Distribution and Use in the Western Empire, edited by A. McWhirr, 45-64. BAR-IS 68. Oxford: British Archaeological Reports.

Castiglione Morelli del Franco, V., and R. Vitale. 1989. "L'Insula 1: Un campione d'indagine socio-economica." RStPomp 3:185-221.

Cerulli Irelli, G. 1977. "Una officina di lucerne fittili a Pompei." In L'instrumentum domesticum di Ercolano e Pompei, edited by A. Carandini, 53-72. Quaderni di Cultura Materiale 1. Rome: L'Erma di Bretschneider.

Ciarallo, A., and E. De Carolis, eds. 1999. Homo faber: Natura, scienza e tecnica nell'antica Pompei. Milan: Electa.

Cuomo di Caprio, N. 1976. "In margine alle fornaci di Pompei.” CronPomp 2:231-40.

- 1995. "Osservazioni tecniche sul tornio da vasaio nell'antichità.” RdA 19:145-52.

Czysz, W. 1982. "Der Sigillata-Geschirrfund von Cambodunum-Kempten: Ein Beitrag zur Technologie und Handelskunde mittelkaiserzeitlicher Keramik." BerRGK 63:281-345.

Della Corte, M. 1954. Case ed abitanti di Pompei. 2nd ed. Rome: L'Erma di Bretschneider. . 1958. "Pompei: Iscrizioni scoperte nel quinquennio 1951-1956.” NSc ser. 8, vol. 12:77-184.

Peña 1999, 31-3.

${ }^{94}$ Excavation in this area would prove problematic, as it lies underneath a tourist path and an orchard situated outside the fence enclosing the zona archeologica. 
Delplace, C. 1978. "Les potiers dans la société et l'économie de l'Italie et de la Gaule au Ier siècle av. et au Ier siècle ap. J.-C." Ktema 3:55-76.

Edwards, B., and M. Anderson. 2007. "Pompeii Via Consolare Study Field Report." 108th Annual Meeting Abstracts. Vol. 30, 85-6. Boston: Archaeological Institute of America.

Eschebach, H. 1970. Die städtebauliche Entwicklung des antiken Pompeji. RM Suppl. 17. Heidelberg: Kerle.

Eschebach, L. 1993. Gebäudeverzeichnis und Stadtplan der antiken Stadt Pompeji. Cologne: Böhlau.

Fröhlich, T. 1991. Lararien und Fassadenbilder in den Vesuvstädten: Untersuchungen zur "volkstümlichen" pompejanischen Malerei. RM-EH 32. Mainz: Philipp von Zabern.

Fülle, G. 1997. "The Internal Organization of the Arretine Terra Sigillata Industry: Problems of Evidence and Interpretation." JRS 87:111-55.

Gasperetti, G. 1996. "Produzione e consumo della ceramica comune da mensa e dispensa nella Campania romana." In Les céramiques communes de Campanie et de Narbonnaise (Ier s. av.J.-C.IIe s. ap.J.-C.): La vaisselle de cuisine et de table. Actes des Journées d'étude organisées par le Centre Jean Bérard et la Soprintendenza Archeologica per le Province di Napoli e Caserta. Naples, 27-28 mai 1994, edited by M. Bats, 1964. Naples: Centre Jean Bérard.

Giampaola, D. 1985. "Ponticelli." In Napoli antica, 302-12. Naples: Macchiaroli.

Hilgers, W. 1969. Lateinische Gefässnamen: Bezeichnung, Funktion und Form römischer Gefässe. BJbBeiheft 31. Dusseldorf: Rheinland Verlag.

Jashemski, W. 1979. The Gardens of Pompeii: Herculaneum and the Villas Destroyed by Vesuvius. New Rochelle, N.Y.: Caratzas.

Kockel, V. 1983. Die Grabbauten vor dem Herculaner Tor in Pompeji. Mainz: Philipp von Zabern.

Kockel, V., and B. Weber. 1983. "Die Villa delle Colonne a Mosaico in Pompeji." RM 90:51-89.

Kramer, C. 1997. Pottery in Rajasthan: Ethnoarchaeology in Two Indian Cities. Washington, D.C., and London: Smithsonian Institution Press.

Mackensen, M. 1993. Die spätantiken Sigillata-und Lampentöpferein von El Mahrine (Nordtunisien). Münchner Beiträge zur Vor- und Frühgeschichte 50. Munich: C.H. Beck.

Maiuri, A. 1927. "Pompei: Relazione sui lavori di scavo dal marzo 1924 al marzo 1926." NSc ser. 6, vol. 3:3-83.

_ 1939. "Pompei: Scavo della 'Grande Palestra' nel quartiere dell'anfiteatro (a. 1935-1939).” NScser. 6, vol. $15: 165-327$.

_.1953-1954. "Due singolari dipinti pompeiani." $R M$ 60-61:88-99.

McCallum, M., and E. Manfredi. 2007. "The Pottery and Finds." RStPomp 18:125-26.

McCarthy, M., and C. Brooks. 1988. Medieval Pottery in Britain $A D$ 900-1600. Leicester: Leicester University Press.

Miller, D. 1985. Artifacts as Categories: A Study of Ceramic Variability in Central India. Cambridge: Cambridge University Press.

Morel,J.P. 1984. "La ceramica e il vetro." In Pompei 79: Raccolta di studi per il decimonono centenario dell'eruzione vesuviana, edited by F. Zevi, 241-64. Naples: Macchiaroli.

Nappo, S. 1997. "Urban Transformation at Pompeii in the
Late 3rd and Early 2nd C. B.C." In Domestic Space in the Roman World: Pompeii and Beyond, edited by R. Laurence and A. Wallace-Hadrill, 91-120. JRA Suppl. 22. Portsmouth, R.I.: Journal of Roman Archaeology.

Oxé, A., H. Comfort, and P. Kenrick. 2000. Corpus Vasorum Arretinorum: A Catalogue of the Signatures, Shapes and Chronology of Italian Sigillata. 2nd ed. Bonn: Rudolf Habelt.

Pappalardo, U. 2001. La descrizione di Pompei per Giuseppe Fiorelli (1875): Con una cronistoria per immagini e la lettera alla Guardia Nazionale del distretto di Castellammare di Stabia. Naples: Massa.

Peacock, D.P.S. 1982. Pottery in the Roman World: An Ethnoarchaeological Approach. London and New York: Longman.

Peña, J.T. 1999. The Urban Economy During the Early Dominate: Pottery Evidence from the Palatine Hill in Rome. BAR-IS 784. Oxford: Archaeopress.

2007. Roman Pottery in the Archaeological Record. Cambridge: Cambridge University Press.

Placidi, S. 2005. "Domus VI, 5, 9-19, 10 (Casa dei Fiori)." RStPomp 16:183-85.

Prachner, G. 1980. Die Sklaven und Freigelassenen im arretinischen Sigillatagewerbe: Epigraphische, nomenklatorische sowie sozial- und wirtschaftsgeschicthliche Untersuchungen der arretinishcen Firmen- und Töpferstempel. Forschungen zur antiken Sklaverei 12. Wiesbaden: Franz Steiner.

Proietti de Santis, R. 2005. “Domus VII, 15, 9-10.” RStPomp 16:197-98.

Pucci, G., and C. Mascione, eds. 2003. Manifattura ceramica etrusco-romana a Chiusi: Il complesso produttivo di Marcianella. Bari: Edipuglia.

Pugliese Carratelli, G., and I. Baldassare, eds. 1990-2003. Pompei: Pitture e mosaici. 10 vols. Rome: Istituto della Enciclopedia Italiana.

Puppo, P. 1995. Le coppe megaresi in Italia. StArch 78. Rome: L'Erma di Bretschneider.

Rieth, A. 1965. "Zur Frage der Römischen Töpferscheibe.” Fundberichte aus Schwaben, n.s. 16:153-55.

Rye, O., and C. Evans. 1976. Traditional Pottery Techniques of Pakistan: Field and Laboratory Studies. Smithsonian Contributions to Anthropology 21. Washington, D.C.: Smithsonian Institution Press.

Spinazzola, V. 1953. Pompei alla luce degli scavi nuovi di Via dell'Abbondanza (anni 1910-1923). Rome: Libreria dello Stato.

Stanco, E. 1988. "Una officina di ceramiche ellenistiche presso Segni." Ricognizioni archeologiche 4:12-42.

Stefani, G. 2006. "La vera data dell'eruzione." Archeo 22: 10-13.

Swann, V. 1984. The Pottery Kilns of Roman Britain. Royal Commission on Historical Monuments Suppl. 5. London: Her Majesty's Stationery Office.

Van der Poel, H., L. García y García, and J. McConnell. 1986. Corpus Topographicum Pompeianum. Pt. 3A, The Insulae of Regions I-V. Austin: University of Texas Press.

Wallace-Hadrill, A. 1994. Houses and Society in Pompeii and Herculaneum. Princeton: Princeton University Press.

Ward-Perkins, J., and A. Claridge. 1978. Pompeii AD 79. 2 vols. Boston: Museum of Fine Arts.

Zimmer, G. 1982. Römische Berufsdarstellungen. AF 12. Berlin: Gebr. Mann. 